\title{
Manufacturing of firearms parts: relevant sources of information and contribution in a forensic context
}

\author{
Denis Werner*, Romain Berthod, Damien Rhumorbarbe, Alain Gallusser \\ Ecole des sciences criminelles, University of Lausanne, Lausanne, Switzerland \\ *Corresponding author, e-mail address: denis.werner@unil.ch
}

GRAPHICAL ABSTRACT

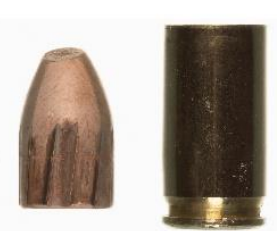

Questioned material

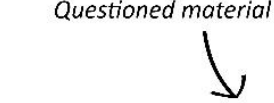

Analysis phase

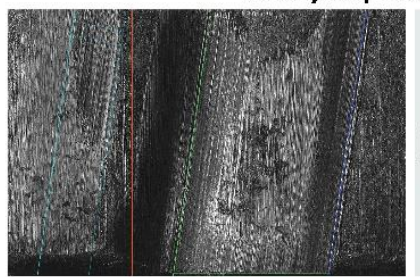

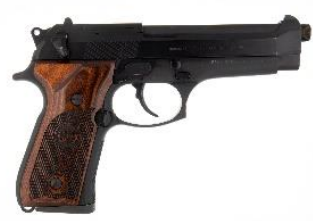

Questioned firearm

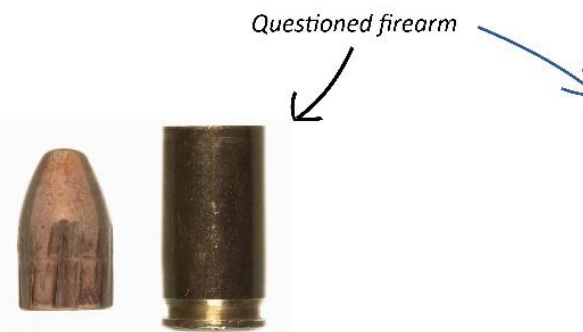

Reference material
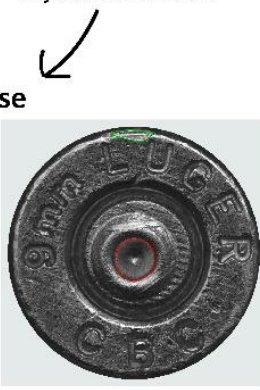

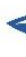

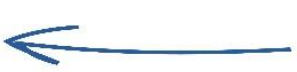

The manufacturing process used to produce parts of a firearm influences the marks left on elements of ammunition discharged with this firearm. A complementary approach relying on forensic literature and online resources is recommended to gather information on the manufacturing process of a given

firearm. Further details can be obtained by contacting manufacturers or visiting their factory. 


\section{ABSTRACT}

In the context of forensic cases involving firearms, a major issue to address is the identification of the firearm used to discharge questioned elements of ammunition - bullets or cartridge cases - found during the scene investigation. When a questioned firearm is available, reference bullets and cartridge cases are produced through controlled test-fires. The marks left on both the questioned and reference elements of ammunition are analysed before being compared. The processes used to manufacture the firearms tend to influence the type and frequency of some of these marks. Knowing how the questioned firearm was produced is a key element to identify the relevant marks for comparison purposes. Finding this information can be challenging, as it is not necessarily publicly available. After presenting the manufacturing processes used to produce the main parts of firearms in contact with the elements of ammunition, this review includes an updated list of processes used by specific manufacturers, relying not only on the literature. The results highlight the necessity to consider a wide range of sources when gathering information about the manufacturing processes. Apart from general and specialized forensic literature, the online content made available by the manufacturers themselves is also a valuable complementary source of information. Contacting the manufacturers or visiting their premises is sometimes necessary to understand the full extent of the processes and how they can influence the marks of forensic interest.

Keywords: Sub-class characteristics, Rifled barrel, Breech face, Firing pin, Extractor 


\section{INTRODUCTION}

When investigating cases involving the use of a firearm, elements of ammunition such as cartridge cases or bullets might be found on a scene of investigation. Subsequently, one of the main questions to be addressed is the identification of the firearm itself. During the firing process, different parts of the firearm are in contact with the elements of ammunition. Since the material used to build firearms is harder than the material of the elements of ammunition are made of, the contact between them will result in significant marks appearing on the surface of the bullet or the cartridge case. For example, the inner surface of the barrel (lands and grooves) leaves lands and grooves impressions and skid marks on the bullet while the breech face leaves traces on the cartridge case head. Such marks bear class characteristics (e.g. number of lands and grooves on the projectile and the relative position of ejector and extractor mark on the cartridge case), as well as potential subclass and individual characteristics. These characteristics are generated on the firearm parts by multiple factors during the manufacturing process and when the firearm is used. In a forensic context, when analysing the marks left by a firearm on a fired bullet or an expanded cartridge case, the ability to distinguish between subclass and individual characteristics is essential. For identification purposes, the former might be misleading since they are shared by several firearms made consecutively with the same tool, as opposed to the latter which are specific to one firearm. Knowing how a firearm is produced is a key information to identify subclass characteristics. Whether it is based on a button, a mandrel forge or a broach, most of the techniques used for the manufacturing of barrels involve a rifling tool. Such a tool carries specific characteristics on its surface that will change over time, depending - for example - on how many times the tool was used to produce barrels. These processes influence their inherent potential for producing subclass and individual tool marks. A rifling tool with such characteristics will produce patterns on the inner surface of the newly rifled barrel. Since the same tool can be used to produce a wide range of barrels, some of them may show similar characteristics called subclass characteristics, particularly if they are produced consecutively. Depending on the rifling method, the number and the nature of subclass characteristics of the barrel will vary. Therefore, a firearms expert has to understand the different manufacturing processes that can vary from one manufacturer to another, as well as the impact of those processes on the marks left by the investigated firearm. It should be kept in mind that subclass characteristics may appear on firearms with serial numbers that do not follow each other. Indeed, when assembling a firearm, the different parts are generally taken at random without respecting any order in regards to the time of each component's manufacture. Moreover, serial numbers are usually inscribed on the firearm parts after passing the test bench and also in a manner unrelated to their time of manufacture.

Reference bullets and cartridge cases in a forensic identification case are usually obtained by firing a questioned firearm in controlled conditions (Werner, Rhumorbarbe, Kronseder, \& Gallusser, 2018). Knowing if the questioned firearm is prone to leave subclass characteristics is a valuable piece of information when analysing, comparing and evaluating the marks left on the questioned and reference bullets. Indeed, these three steps are part of the identification process referred to as "ACEV" for Analysis - Comparison - Evaluation - Verification ${ }^{1}$, introduced by David R. Ashbaugh in his book

\footnotetext{
${ }^{1}$ The purpose of the analysis phase is to determine the characteristics (marks) of the questioned and reference materials. Then comes the comparison of the characteristics of the marks with each other. All the observations
} 
about the quantitative and qualitative friction ridge analysis (Ashbaugh, 1999). It is therefore important to gather information of how the parts of the firearm are manufactured to facilitate the process of these four steps. Firstly, knowing the manufacturing processes of the different parts of a weapon will guide the analysis and comparison of the marks observed by facilitating both the recognition and the distinction of subclass and individual marks. Then, for evaluation purposes, it is essential for the firearm expert to understand the characteristics originating from the manufacturing process in order to properly assess the value to the observations made during the comparison step. However, documentation of the manufacturing process of firearms parts - such as the barrel or the breech face - is scattered across different sources.

Accordingly, the purpose of this review is twofold. First, it aims at compiling the available information on the manufacturing process of firearms parts, focusing on the barrel and the breech face manufacturing. Each manufacture technique will be explained and illustrated with examples of brands and models. Second, guidelines on how to search for information related to the manufacturing of firearm components will be presented, as well as examples of processes used by specific manufacturers.

\section{RELEVANT SOURCES OF INFORMATION}

Two main sources were used to gather information on the manufacturing process of firearms parts. First, a classic literature review approach was adopted by identifying relevant books or scientific journals specializing in forensic science, more specifically in firearms expertise. Then, the online content made available by a range of manufacturers was studied, as well as the information obtained by visiting the premises of 6 manufacturers between 2006 and $2020^{2}$.

\subsection{Publications focused on forensic firearms}

Six main references about firearms in a forensic context include information about the manufacturing process of firearm parts: Di Maio (1999), Heard (2008), Warlow (2012), Gallusser (2014), Nichols (2018) and Monturo (2019). However, even if those references describe the processes, they are not necessarily a source of information detailed enough to link a specific manufacturer - or a model - to a process. Many articles were published in the AFTE Journal, the official publication of the Association of Firearm and Tool Mark Examiners (AFTE), or in other different forensic journals : Biasotti (1981), Murdock (1981), Bonfanti (1997), Bonfanti and De Kinder (1999), Smith (2011), Bolton-King et al. (2012a) and Bolton-King (2017). These articles describe the exchange of information on methods and practices concerning firearms and their manufacture, as well as to various studies on the identification of firearms using ammunition elements. For example, the article by Bonfanti (1997) is mainly about the manufacturing processes of certain parts of firearms, without referencing specific manufacturers. Subsequently, Bonfanti and De Kinder (1999) published an article about the influence of manufacturing processes on the identification of projectiles. The article includes a table summarising

are then evaluated against the proposals propose by the parties. Finally, the verification of the whole work is carried out by a peer, ideally without knowledge of the case and the results.

2 The authors had the opportunity to visit the following manufacturers factory: Sphinx Systems Limited (Switzerland, 2006), Fredec AG (Switzerland, 2006), Carl Walther (Germany, 2007), Pietro Beretta (Italy, 2020), Sabatti (Italy, 2020) and Fratelli Tanfoglio SAS (Italy, 2020). 
the results of studies carried out on bullets fired by firearms with serial numbers in sequence or close to each other, as well as the manufacturing process used to rifle the barrel of the weapons used in each case. Kolbe (2010), on the its website, describes the approach and operations adopted by the manufacturer for the making of a rifle barrel by outlining the main processes involved in turning a bar of steel into a rifled barrel. Smith (2011) when studying more than 50 different companies manufacturing firearms lists their make, model, calibre, type, and barrel rifling method. Another article Bolton-King et al. (2012a), comparing transitions between lands and grooves after different manufacturing processes, also includes a list of firearm models and the technique used to rifle their respective barrel. Warlow (2012) describes in his book all the different machining process which could be used in the manufacturing of firearm parts. The book in French by Gallusser (2014) includes a detailed explanation of the manufacturing process of the barrel, the breech and the firing pin. BoltonKing (2017) provides the rifling methods used by a large number of $9 \times 19 \mathrm{~mm}$ handgun manufacturers and for some firearms the number of lands and grooves, twist direction and rifling profile. Specifically mentioning the evaluation of subclass characteristics, Nichols (2018) explains the various tools and processes used in the firearm parts manufacturing. Finally, a book by Monturo (2019) presents in detail - along with photographs and many examples - the different firearm manufacturing techniques and barrel manufacture, focusing on rifling processes.

While mentioned and described in publications about firearms identification, the manufacturing processes are generally difficult to link to a specific model of firearm. It is however the information required in the context of firearm identification, to distinguish the different types of traces left by firearms. To complement the literature, a possible approach, highlighted in the AFTE Journal article by Smith (2011), is to contact manufacturers in order to gather information about their processes.

\subsection{Research directly in firearms manufacturers}

Most of the information obtained in forensic and firearm publications is fragmentary and should be supplemented and verified if possible, with information from the manufacturers directly. The welldocumented list of firearms manufacturers on Doyle's FirearmsID webpage (Doyle, 2011) - which also includes each manufacturer's website - was used to orientate the research from the manufacturers' perspective. For some of them, the technical data sheets and presentation catalogues for the various firearm models provided information on the firearms manufacturing processes. Others only listed data such as the diameter of the barrels, the width and number of the grooves and lands, as well as the material constituting the barrel. When applicable, the discussion forum of each site was consulted, even if some manufacturers might be reluctant to communicate through this type of media. Indeed, a discussion thread from 2010 on the website of the manufacturer Beretta (http://www.berettasupport.com/service/pg_ask_question.htm), showed that information about their manufacturing process cannot be made public. As opposed to discussions, online content explaining the different stages of the production of their firearms can be published by different companies. For example, Sturm, Ruger \& Co., Inc. have published a series of sixteen videos presenting their Newport facility, the production of their firearms from beginning, the first steps in designing firearms, to end of the safety checks and fine-tuning, as well as the production of their barrels by cold hammering (RugerFirearms, 2014a, 2014b, 2014c, 2014d, 2014e, 2014f, 2014g, 2014h, 2014i, 2014j, 2014k, 2014l, 2014m, 2014n, 2015a, 2015b). 


\section{THE MANUFACTURE OF FIREARMS PARTS}

The following paragraphs will describe the manufacturing process of different firearms parts. Generally, the rifling processes of barrels are more often described in the literature. It is also important to underline the evolution of weapons production from handcrafted processes to productions relying on computer numerical control (CNC). These automated processes can be used for the entire production of the firearms' parts or only for some steps of the process (e.g. rough processing of components before a hand finishing step, or vice versa) (Warlow, 2012).

\subsection{Barrels}

\subsubsection{Drilling of the barrel blank}

Manufacturing a rifled barrel relies on two initial steps that are practically mandatory regardless of the type of process used. The manufacturing starts with the selection of a rod of raw steel bar generally in carbon, chrome molybdenum steel or stainless steel to resist pressure, friction and vibration (Kolbe, 2010; Monturo, 2019). During the second step, the bar is drilled from end to end through the centre to produce a long straight hole forming the bore with a diameter smaller than the desired one and a very coarse inner surface. Usually the bar rotates and a fixed asymmetrical gun drill (drill bit) in tungsten carbide is used to drill the hole, the barrel is also pulled over the reamer (Haviland, 2001; Kolbe, 2010; Monturo, 2019)). Then, a reaming tool is used to smooth the internal contour of the drilled steel bar to improve the inner surface of the bore. A helical or straight barrel reamer (see Figure 1), in most cases made of tungsten carbide, is used to give the barrel blank its proper dimension. The marks produced by drilling will not end up in the finished barrel if a reaming is carried out. However, the marks in the form of circular rings produce by the reaming process can be seen in the barrel after the rifling process. Once these processes are completed, a drilled barrel blank can still undergo different treatments to ensure greater strength. A polishing step can also be carried out before rifling.

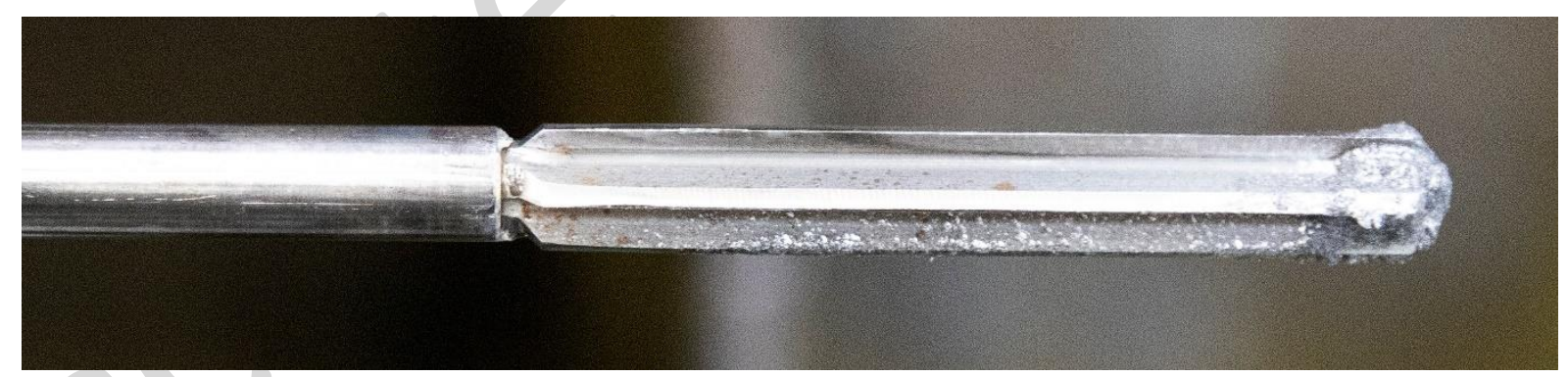

Figure 1. A straight barrel reamer.

The rifling process generates the grooves and lands characterising the barrel of a rifled firearm. Historically, material removal processes were used to define the grooves by cutting or scraping the inner surface of the drilled barrel blank (Bolton-King et al., 2012a). During the $20^{\text {th }}$ century, new swaging methods such as button rifling or hammer forging - not based on material removal - were subsequently developed. This distinction is commonly used in the literature to describe the evolution of rifling processes that would transform the drilled barrel blank into a rifled barrel (Biasotti, 1981; Bonfanti, 1997; Gallusser, 2014). Nowadays, the production of barrels is principally done with a CNC machine. Currently, the different rifling forms are a conventional rifling with lands and grooves or 
square or polygonal (Heard, 2008). These last two types of rifling have no lands (no sharp edges) but flanks who consist of a rounded profile. The polygonal rifling was developed by Heckler \& $\mathrm{Koch}^{\circledR}$ in the 1960s for the MG3 machine gun (Dallhammer, 2018).

\subsubsection{Rifling based on metal removal}

Hook and scrape cutting are two relatively similar processes based on metal removal. A hook cutter is equipped with a single hook shaped cutter (crochet hook) at its end to dig one groove at a time when it is pushed into the barrel (Biasotti, 1981; Bonfanti, 1997; Heard, 2008; Kolbe, 2010; Murdock, 1981). Conversely, the scrape cutter has multi-point cutters inset into the opposed sides that can scraped a minimal of two opposed grooves to all grooves at a time. The hook cutter is pulled through the barrel ten to eighty times in the same groove in order to obtain the desired groove depth, while the scrape cutter requires twenty to eighty passes to form even number of grooves. The rifling tool is actioned manually using a rifling machine ${ }^{3}$, on which the barrel or the tool is turned on itself to create the rate of twists (pitch) (Gallusser, 2014; Thompson, 2015). Even if scrape cutter rifling requires less time to produce grooves, both processes are time-consuming and incompatible with large-scale manufacture since the cutter may require several sharpening or even replacement (Biasotti, 1981; Bonfanti, 1997). Hook rifling can be identified by the presence of the same longitudinal striations in all grooves, because the same hook cutter is used for every groove (Heard, 2008). Scrape cutting leaves the same characteristic marks except if a different scraper is used for each groove, leaving different marks on the grooves.

Two types of broaching are mentioned in the literature, depending on the type of broach (Bonfanti, 1997; Heard, 2008; Warlow, 2012). The first, gang broaching, is carried out with a rifling tool in the form of a rod equipped with twenty-five to thirty steel spaced discs with teeth of decreasing size. On these discs is the negative image of the rifling's final diagram. Unlike manual processes using the hook or scrape cutting, a broaching tool passes only once through the barrel blank. Its rotation is carried out by hydraulic pressure. As the teeth on the discs are less and less prominent, the smaller discs cut first and the grooves become progressively deeper. The second process, called single broaching, uses consecutively twenty to sixty different broaches of increasing size instead of one. Several passages will therefore be necessary with this technique. Each broach can rifle several hundred barrels before being sharpened and a few thousand before being replaced (Biasotti, 1981; Monturo, 2019). In the barrel, grooves will show longitudinal striations produced by the broach while the lands will show reaming marks by the reamer. Consequently, when observing marks left on bullets fired with a broached barrel, groove impressions could show longitudinal striations which might have subclass characteristics (shared by barrels consecutively rifled), as opposed to land impressions (see Figure 2a).

\footnotetext{
${ }^{3} \mathrm{~A}$ complete history of the different rifling machines and their evolution is available online on the Kolbe's website (2010).
} 

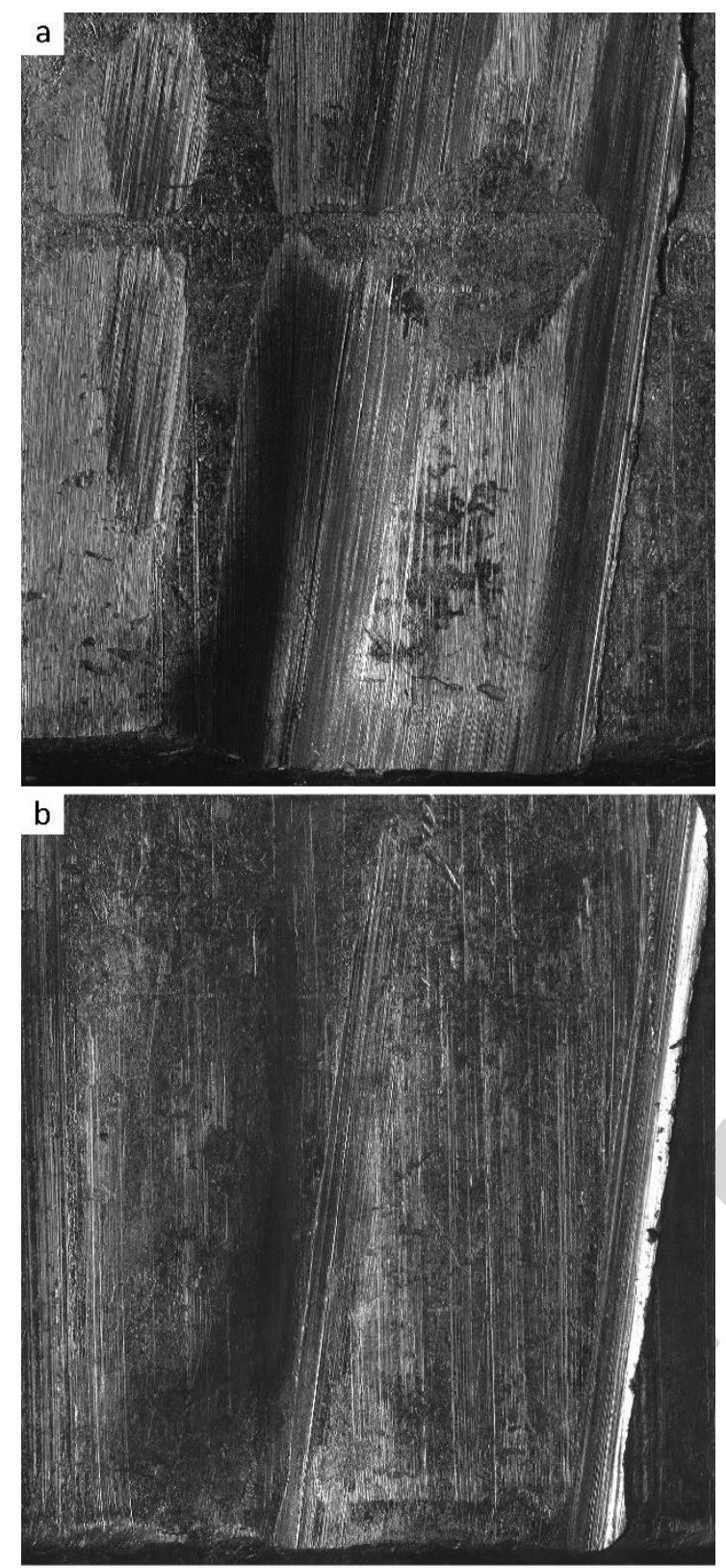

Figure 2. Lands and grooves impressions on the bullets scanned with the Evofinder ${ }^{\circledR}$ ballistics identification system (ScannBI Technology Ltd, version 6.5.0.122) left on the same ammunition ( $9 \times 19 \mathrm{~mm}$ Parabellum, Magtech, model 9B, FMJ, $124 \mathrm{gr}$ ) by three semi-automatic pistols manufactured by different rifling process: (a) Beretta 92FS (broaching), (b) Walther P99 (button rifling) and (c) Steyr M9-A1 (cold hammer forging).

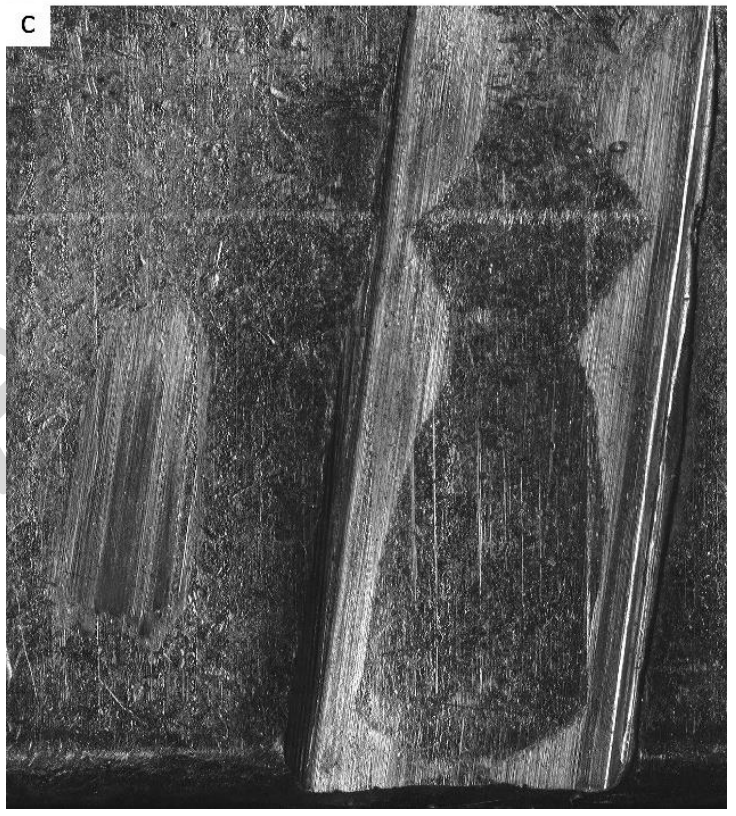


The electrochemical machining (ECM) relies on the electrolysis principle. It was used for the first time in 1920 by the German manufacture Krupp, before being patented in 1953 in the United States (Dallhammer, 2018; DeFrance \& Arsdale, 2003; Heard, 2008; Papke, 1988). ECM forms lands and grooves thanks to a controlled dissolution of the barrel metal by a conductive fluid (the electrolyte) which is subjected to a high density current. One of the electrodes (cathode) is a mandrel - a long plastic cylinder smaller than the desired bore diameter - bearing spiralling metal strips which shape the rifling pattern according to desired shape of the grooves. The mandrel is inserted into the barrel blank which acts as the anode (DeFrance \& Arsdale, 2003; Heard, 2008; Mahdavinejad \& Hatami, 2008; Papke, 1988). The system is then immersed in the electrolyte, a saline solution - such as sodium nitrate or sodium chloride - and an electric current is applied. The electrode is then moved through the barrel and twisted to create the grooves at the desired rate of twists. As the current moves from the steel bar to the electrode, the metal is removed by electrolysis, producing the grooves of the barrel by duplicating the shape of the metal strips on the mandrel. The electrolyte flows through the barrel under pressure to remove the reaction products (DeFrance \& Arsdale, 2003). ECM rarely requires the rifling mandrel to be replaced. The mandrel does not require any cleaning or maintenance since the metal strips are never in physical contact with the barrel. Besides, the pressurized electrolyte flow prevents the formation of electrolysis reaction products (DeFrance \& Arsdale, 2003). In fact, the mandrel is replaced when the plastic cylinder, which is in contact with the barrel to provide proper spacing and centring, is too worn and therefore too small. The electrochemical method will preserve the reaming marks in the lands and the sides of rifling have distinctly rounded shoulders (Dallhammer, 2018; Warlow, 2012). Furthermore, random pockmarks are presents in the groove where the metal has been dissolved from the surface by electrolysis (Monturo, 2019). Simplified ECM methods are used to produce rifling grooves in barrels made from steel tubing in homemade guns (Hays, Ivan, \& JenzenJones, 2020).

Electrodischarge machining (EDM), a process very similar to ECM, can also be used to manufacture the firearm dies, and not as a rifling process. The firearm part is manufactured using electrical sparks. The part and an electrode are immersed in dielectric liquid and subjected to an electric voltage allow vaporising and melt material away by electrical discharges (Bolton-King, 2017; Nichols, 2018).

\subsubsection{Rifling based on metal deformation}

Mandrel rifling is based on metal compression and does not involve any removal of material from the barrel. Indeed, a mandrel forge, featuring the negative impression of the desired rifling, is introduced into a drilled barrel blank. Straightening rollers are then used to compress the barrel to the mandrel forge (Murdock, 1981). The barrel will acquire the rifling pattern from the mandrel, which will be subsequently unscrewed from the barrel. This technique is very similar to the hammering process explained below. However, it is limited to short handguns barrels (Bonfanti, 1997). A mandrel forge is used to rifle 1000 to 2000 barrels depending on its quality.

Button rifling (buttoning or button swaging), patented in 1920, relies on an elliptical button with the negative contour of lands and grooves as illustrated in Figure 3. Unlike mandrel rifling and hammering, the button has a larger diameter than the inside of the barrel blank. Its penetration into the barrel is carried out under hydraulic pressure (2500 to 2800 bars). When passing through the barrel, the button turns on itself (producing the lands and grooves of the required twist) as the bore expands to take the negative form of the profile manufactured on the button (Austin, 1970; Biasotti, 1981; Gallusser, 
2014; Kolbe, 2010). A button made in tungsten carbide can be used to manufacture approximately 1000 barrels of AR-15, semi-automatic pistols APX or assault rifle ARX160 (visit the manufacturer, 2020) and 2000 pistol barrels before being replaced (Gallusser, 2014; Monturo, 2019). A particular application of buttoning, referred to as Micro-Groove rifling, is used among others by the Marlin Firearms company (Bonfanti, 1997; Di Maio, 1999; Glass \& Gibson, 1997). For this process, the button used for the rifling is made in calcium carbide and includes 12 to 20 negative grooves shallower than for a conventional rifling. This rifling process increases the cross section of the bore, reducing the resistance of the barrel on the projectile. Therefore, the accuracy of the barrel is improved due to both a higher velocity and a lower pressure (Robinson Jr, 1963). Button rifling is generally only used on cheaper firearms, particularly those of 0.22 calibres (Heard, 2008; Kolbe, 2010). The concentric marks of the reaming process are still present but slightly smoothed. The button will leave very few longitudinal marks (see Figure $2 \mathrm{~b}$ ). However, if the button has slight damage or other fault, several well-defined striations might appear in the bore, and even in consecutively rifled bores(Dallhammer, 2018; Heard, 2008). Similarly, the rifling edges may present chips and sideflow if the button edges cut through the metal instead of displacing it (Monturo, 2019).

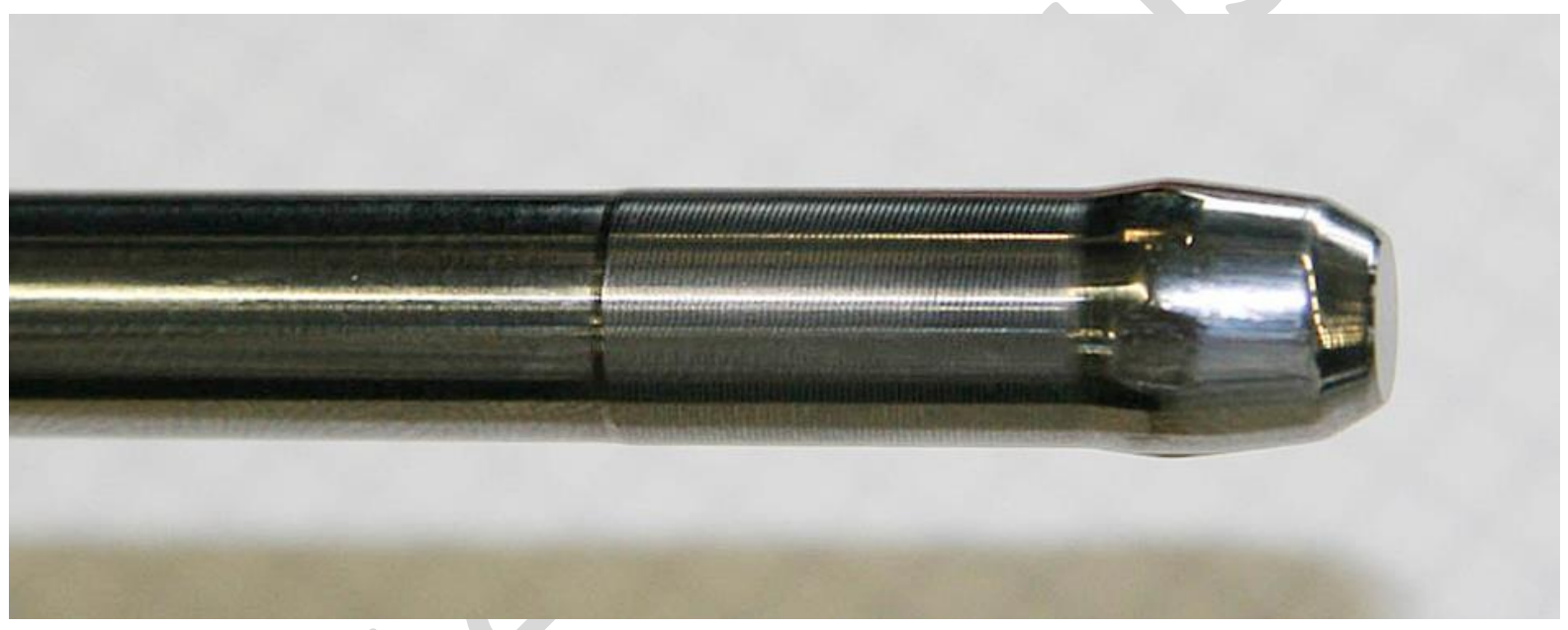

Figure 3. An elliptical button with the negative imprint of lands and grooves.

Cold hammer forging (or hammering), developed in 1940 by Mauser for the MG 42 machine gun, also relies on a mandrel - with a negative contour of the grooves and lands - usually made of tungsten carbide or special steel (see Figure 4) (Bonfanti, 1997; Kolbe, 2010; Murdock, 1981). In order for the mandrel to be introduced into the barrel blank, its diameter is smaller than the diameter of the barrel. After the mandrel is introduced into the barrel by hydraulic pressure, the outside of the barrel is hammered onto the mandrel by multiple hammer radially moving (see Figure 5). The pressure induced by the hammer blows will create the rifling. Throughout this process, the barrel turned on itself, allowing the rifling to create the rate of twists (pitch). The mandrel can be used to manufacture 2000 barrels before being replaced unless it breaks beforehand (e.g. due to the non-homogeneity of a barrel steel). The manufacturer Heckler \& Koch ${ }^{\circledR}$ also uses this manufacturing process for its polygonal rifling where the bore is hexagonal in cross-section (AFTE Journal, 1973; Haag, 1977). Instead of grooves and lands, the rifling pattern has rounded rectangular lands (Bonfanti, 1997). Generally, since cold hammer forging methods relies on compressing the barrel, a regular helical pattern can be observed on its outer surface (Heard, 2008; Warlow, 2012). The firm of Steyr-Mannlicher leaves this pattern on their sporting rifles barrels to indicate the quality nature of the manufacturing process. However, in the 
absence of post rifling treatment, the imperfections of the drilling process will remain on the final profile of the barrel during the hammering (Monturo, 2019). The Sabatti company has patented a new rifling profile called Multi-Radial Rifling (MRR) System for the production of all barrels of theirs shooting and hunting rifles by cold hammer forging (Sabatti's website: https://www.sabatti.it/en/mrrsystem-rifle-barrels). This rifling system has been developed for the .308 and .246 calibres, and it is considered as a semi-polygonal rifling. This system relies on a different rifling geometry. The diameter of the barrel calibre is very close to the diameter of bullet allowing a better gas tightness. Thus, the gases do not precede the projectile when the shot is fired, resulting in a higher bullet velocity than with conventional rifling systems. The overall accuracy of the barrel is increased. Less residues from the bullet are left in the barrel, which requires less cleaning. Finally, this rifling process produces barrels of better quality over time. Since hammer forging is based on metal deformation or displacement, this process leaves few individual characteristics in the lands and grooves as illustrated in Figure 2c. At the end of the process, the mandrel is forcibly retired from the barrel, which can leave scratches.

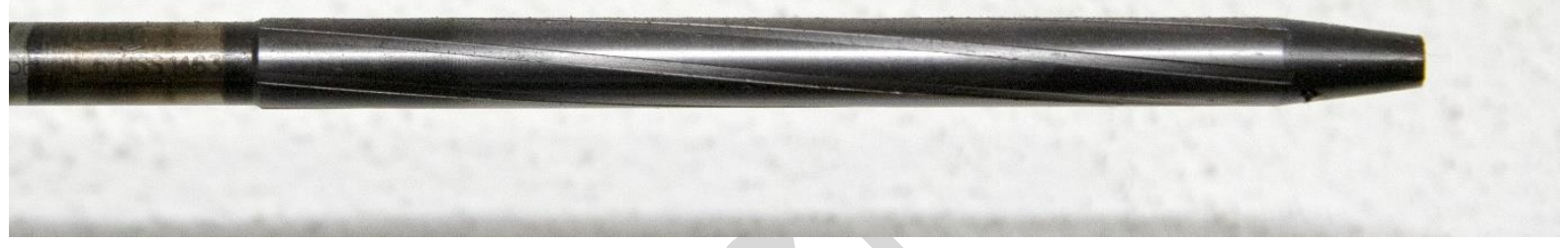

Figure 4. A tungsten carbide mandrel.

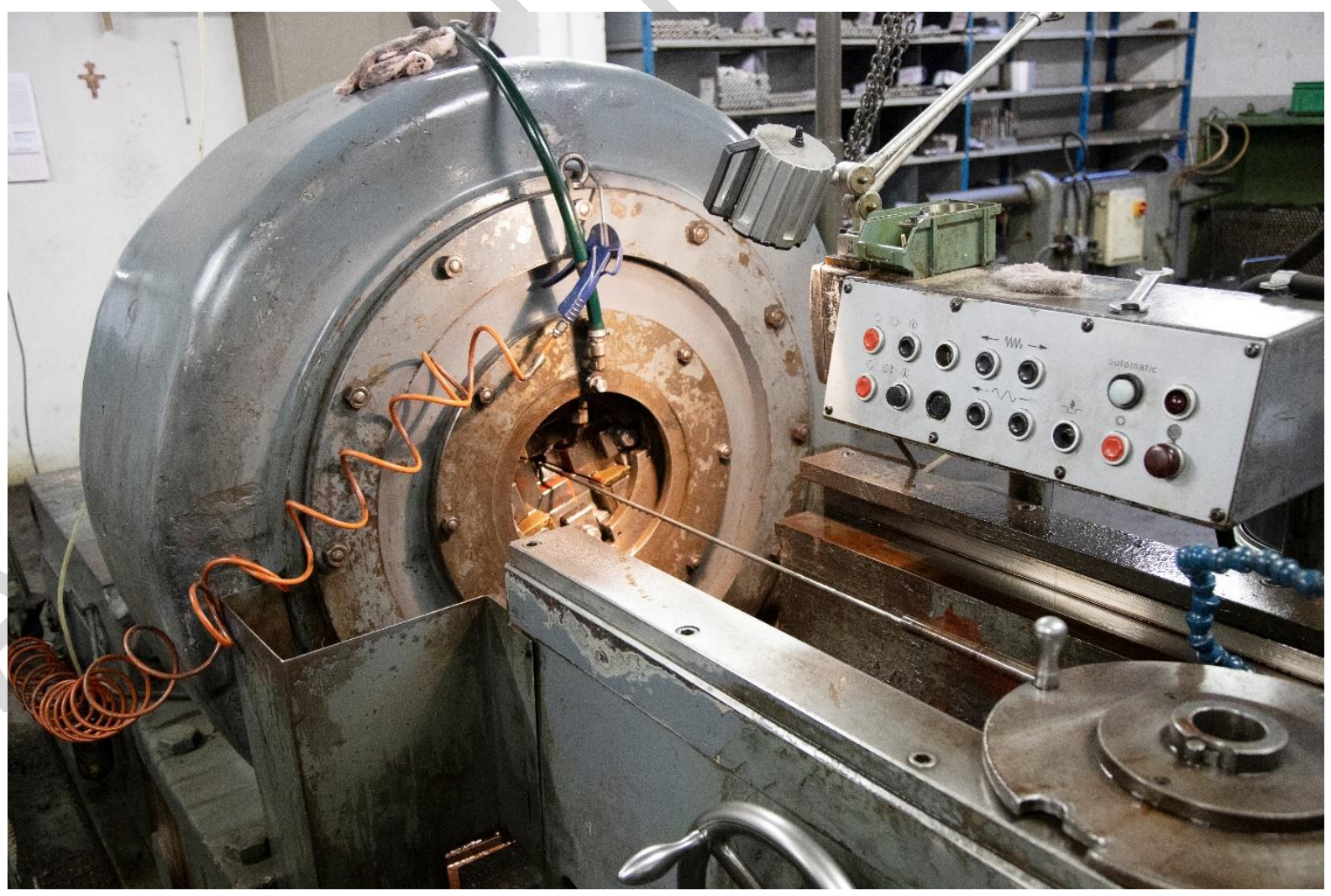

Figure 5. A hammer forging machine with a mandrel introduced into a barrel blank. 


\subsubsection{Investment casting method}

Investment casting, also called lost wax process, does not fall into one of the previous categories (Chenow \& Lemmer, 1994; Price, Lee, \& Rosen, 2008; Warlow, 2012). Despite minor variations between manufacturers, the general principles and application are universal across the industry. First, a die is produced. Then, wax or plastic is injected into the die to create a previously defined pattern. Several wax or plastic patterns are attached to a central tree or sprue. The entire patterns are cleaned in a chemical bath, drained, immersed in a ceramic slurry, then dipped into fine sand. The last two steps are repeated several times to obtain coated ceramic shells. The wax or the plastic is then melted by placing the ceramic shell in a high temperature oven. Steel is then injected and hardened in the ceramic mould (by gravity, vacuum pressure or centrifugal force) which is eventually broken away.

Chenow and Lemmer (1994) give more information about the investment casting method applied in the Precision Unlimited firm. So does Price et al. (2008) for the firm Munitions International Laboratories Inc. (MILI), producer of the Thunder Five revolver. Aero Metals, an engineering-centric investment casting specialist firm, has published an online video about this process, illustrating the different steps of the manufacturing process (Design2PartTradeShow, 2015). Similarly, the Sturm, Ruger \& Co., Inc. have also released online videos manufacture process of their firearms, including the investment casting method (RugerFirearms, 2014a, 2014b, 2014c, 2014d, 2014e, 2014f, 2014g, 2014h, 2014i, 2014j, 2014k, 2014l, 2014m, 2014n, 2015a, 2015b). According to Price et al. (2008) and Monturo (2019), MILI uniquely create rifled barrels by investment casting process, as opposed to other manufacturers producing rifles barrels using a conventional rifled method (cutting or swaging). Indeed, investment casting is less commonly used to produce rifled barrels as it produces a material not able to absorb the relatively high pressure produced during the discharge of a cartridge. This process might not be suitable for the accuracy required for rifle barrels.

Other parts of the firearm (e.g. the breech, the frame, the trigger, etc.) can also be produced using this process (Price et al., 2008).

\subsubsection{Post-rifling treatment}

Once the rifling process is complete, the barrels can still undergo shortening and heat treatments by electrodes where locally the barrel is subjected to particularly high stress and pressures during firing (Bonfanti, 1997; Gallusser, 2014). An optional step called crowning (i.e. shortening of the muzzle by a few millimetres) protects the final part of the rifling and prevents gas leaks when the projectile exits.

Before being examined for quality control, a polishing step can be applied using ultrasonic technique or abrasive material (lapping, honing and ball burnishing), in order to remove inclusions and imperfections, smooth the bore and standardize its diameter (Gallusser, 2014; Heard, 2008; Kolbe, 2010; Monturo, 2019; Nichols, 2018; Warlow, 2012). Lead lapping consists of the introduction of a lead plug coated with oil with fine abrasive material around a rod previously inserted into the barrel. The cooled lead will then have taken the shape and the same diameter as the bore of the barrel. Back and forth movements will then polish the barrel, leaving a matt finish. The bore of the barrel can also be burnished using a mandrel with abrasive sticks (honing) or a hard steel ball (ball burnishing) (Heard, 2008; Warlow, 2012). Lapping and honing are mainly applied to higher-end or hammer-forged barrels (Monturo, 2019). The barrel bore of higher-end firearms and military rifles may be chromium plated to enhance the resistant to corrosion, metal fouling, bore wear and other inclusions (Heard, 2008; Monturo, 2019; Warlow, 2012). 
The subclass characteristics present on the tool will be transferred more or less easily depending on the rifling method used. Indeed, there is a distinction according to the way the working surface of the tool moves in regards to the barrel (Nichols, 2018).

\subsection{Breeches, firing pins and extractors}

While a combination of specialized literature and online sources provide complete overview of barrel production, the processes using to manufacture other firearms parts such as breech bolts (slides), firing pins and extractors, are less often described.

The breech face can be produced by using a milling machine or sanded by hand (Bonfanti, 1997). In general, the factory receives a steel or titanium bar that already has the shape of the slide blank. The blanks are cut and milled first internally and then externally, using computer assisted equipment. The corners are then filed and rounded, so that the breech face must be cut out to obtain its rectangular shape (Gallusser, 2014). To do this, a long cutter (broaches) is used with an ever-longer set of teeth, cutting deeper and deeper. It reaches the breech face through the already drilled ejection window (Bolton-King et al., 2012a; Gallusser, 2014; Lightstone, 2010). These tools must be changed every 100 to 400 milled parts (Gallusser, 2014). Finishing work might be applied to the breech face, together with the slide. This manufacture method is also referred to as broaching (Monturo, 2019). The surface of the breech face will be altered subsequently when the firing pin hole is drilled through it (Lightstone, 2010). Some manufacturers use the wire EDM process as a method to cut the breech faces (Monturo, 2019). A wire is used as a thermal conductor for metal removal. Other manufacturers rely on investment casting method to produce breeches. Metal injection moulding, with a final glass beading (Thompson, 2015), or milling by a rotating endmill (Monturo, 2019) are also mentioned in the literature. The most commonly encountered types of firearms that are manufactured using this method are Cobray M-11, Intratec Tec-9, Uzi firearms, Avtomat Kalashnikova (AK) rifles, and Armalite Rifle (AR) style rifles (Monturo, 2019). Depending on the method, the marks left on the cartridge head are influenced by the surface of the breech face and can be parallel lines, concentric circles, arcs or smooth patterns (Gallusser, 2014).

The firing pins are made from a steel rod that is attached to a rotating mandrel which moves laterally around the tools, activated through CNC (Gallusser, 2014). As illustrated in Figure 6, the firing pin is then polished by small abrasive stones with a detergent as a lubricant (tumbling). The tools used for the manufacturing are not sharpened but changed after 2000 pieces. The firing pins are then hardened by a heating process and finally burnished by a surface treatment or plated with chrome. The firing pins can also produce less accurately by blank stamping, or by metal injection molding (MIM) (Monturo, 2019). Concentric marks can be observed if the firing pin is not properly polished. Matty and Johnson observed this type of marks on Smith \& Wesson firing pin (Matty \& Johnson, 1984). 


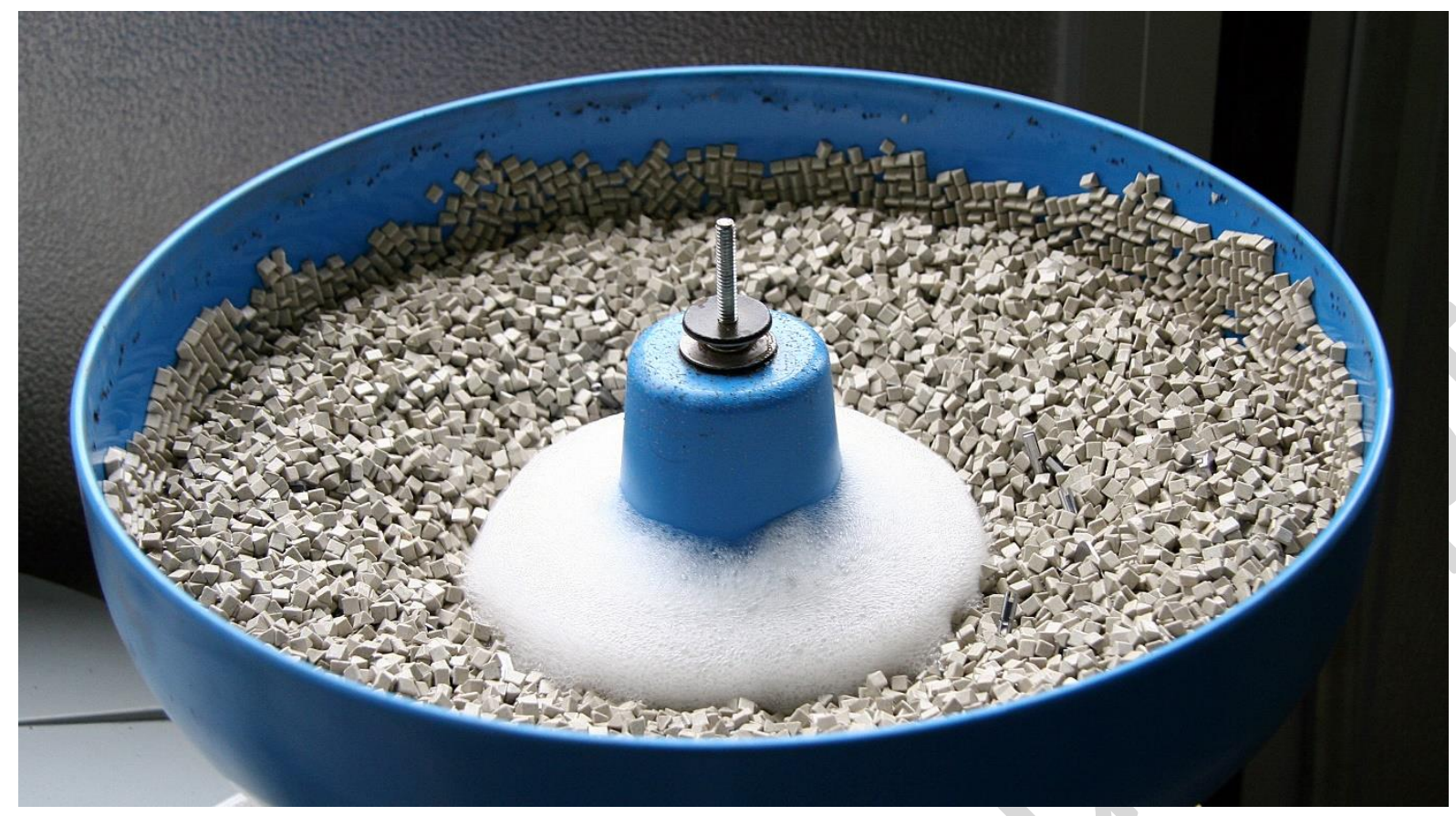

Figure 6. Tumbling process: small abrasive stones and detergent.

An extractor can be manufactured from a single piece of metal bar stock by a combination of milling cutters can be used to progressively removing amount of metal (Nichols, 2018) or by blank stamping (Monturo, 2019).

Depending on the manufacture, minor adjustments or finishing can be applied to each of these parts. This is usually a manual process (e.g. with abrasive paper), leaving different characteristics from one part to another.

\section{GATHERING INFORMATION BY MANUFACTURER}

The results will be provided in alphabetical order of manufacturers, first for the barrels and then for the other parts of firearms (breech face, the firing pin, etc.). These findings are also summarized in Tables A1 and A2 in Appendix. The well-structured and detailed results obtained by Smith (2011) and Bolton-King (2017) are not included in the following paragraphs or in Tables A1 and A2 in Appendix. It is worth noting that the processes identified for each manufacturer may have changed or evolved over time for a given model (Monturo, 2019). Similarly, a manufacturer relying on different techniques, may have switched from one to another. Regarding barrel chambers, Krcma (1996) listed models of firearms showing fluted and annular barrel chambers.

\subsection{Rifled barrels}

Bauer Firearms Corporation. Chenow and Lemmer (1994) mentions that Bauer Firearms Corporation is using investment casting for the manufacture of their barrels.

Bushmaster. In the past, the Coronet Manufacturing Company occasionally supplied barrels rifled by button rifling and broaching for Bushmaster (Robinson, 1982). However, on the official Bushmaster's website (https://secure.viewer.zmags.com/publication/bd31fa3c\#/bd31fa3c/1), a catalogue 
including the ACR series indicates that the manufacturing process used for these models is hammer forging.

Carl Walther. The barrels of Carl Walther are exclusively manufactured by button rifling (visit the manufacturer, 2007). This is mentioned in the literature for the PP and P99 models (Bolton-King et al., 2012a; Bonfanti \& De Kinder, 1999).

Colt's Manufacturing Company. Biasotti (1981) states that the Colt .22 barrels were produced by button rifling. Glass and Gibson (1997) confirm this information, adding that button rifling is also used across different Colt models. Murdock (1981) mentions that the barrel of the Colt .45 ACP was rifled by scrape cutting. The article by Chenow and Lemmer (1994) reports that Colt also used investment casting, without any information about a model in particular. More recently, Bolton-King et al. (2012a) mentions that broaching is used for the rifling of the Colt All American 2000 barrels.

Coonan Arms. The electrochemical machining (ECM) is used to rifle the barrels of Coonan Arms Model B chambered in .357 Magnum (Lansing, 1988; Papke, 1988).

Eddy. An article describing a brief history of Eddy's company indicates that button rifling was used to produce barrels, without any additional information (Sugarman, 1982).

Fabrique Nationale (FN) Herstal. Hammer forging is used to rifle the barrel of the FN Browning HiPower MK 1 (Bolton-King et al., 2012a).

Fabryka Broni (F. B.) "Łucznik" Radom. Broaching is used for the rifling of the barrels of the F. B. Radom Vis Model 35 (Bolton-King et al., 2012a).

Fratelli Tanfoglio SAS. Their classic or polygonal rifled barrels are produced by the Lothar Walther factory, either by button rifling or hammering (visit the manufacturer, 2020).

Glock. An article dedicated by Garland (1987) states that the barrel of the Glock 17 model is rifled using hammer forging and the pattern of the rifling is hexagonal. The same information is mentioned in for the Glock 19 (Bolton-King et al., 2012a). As there were no other results for Glock, a search was carried out on the site of this manufacturer (https://us.glock.com). Several information come out but none of any rifling process of the described firearms. We learn that the Glock 17 compatible with $9 \times 19 \mathrm{~mm}$, the Glock 22 for .40 calibre, the Glock 20 for $10 \mathrm{~mm}$ Auto calibre, the Glock 25 for .380 ACP and Glock 31 for .357 Magnum have grooves with a right twist and a hexagonal pattern. Similarly, the Glock 21 for a calibre of .45 ACP and the Glock 37 for .45 G.A.P. have grooves with a right twist but an octagonal pattern. The latest generation of Glock handgun (Gen5 model, Glock 42, 43 and 44) (Christen \& Jordi, 2019) is equipped with a new type of polygonal barrel referred to as Glock Marksman barrel (GMB) which delivers improved accuracy according to Glock's website (https://eu.glock.com/en/technology/gen5).

Heckler \& Koch (H\&K). H\&K mainly uses hammer forging to rifle the polygonal barrels of its handguns, such as the P9S and USP models. The same applies to the .40 Smith \& Wesson model with a conventional barrel six grooves and a right twist (AFTE Journal, 1973; Bonfanti \& De Kinder, 1999; Valdez, 1997). 
Iver Johnson \& Painfield carabine. The Coronet Manufacturing Company occasionally supplied barrels rifled by button rifling and broaching for Iver Johnson \& Painfield carbine (Robinson, 1982).

Jennings Firearms, Bryco Arms, Jimenez Arms. This company mainly uses the broaching process to rifle their barrels (Welch, 2013).

John Slough of London. The Spitfire MK II model is rifled by button rifling (Bolton-King et al., 2012a).

Lothar Walther. This manufacturer supplies barrel blanks or processed rifled barrel. Lothar Walther's website (http://www.lothar-walther.de) indicates that button rifling is used for 240 different calibres, including those for precision hunting.

Lorcin Engineering. Specific articles about the L25 pistol (Carr, 1992) and the L380 model (Bonfanti \& De Kinder, 1999; Collins, 1997) show that the barrel are manufactured using button rifling.

Marlin Firearms. Glass and Gibson's article discuss the outcomes of their visit to the Marlin factory and mention that the .22 calibre barrels were rifled by button rifling (Glass \& Gibson, 1997). Bonfanti and De Kinder (1999) confirm this information, without specifying any model, except for the 336-R.C. carbine, rifled by micro-groove buttoning.

Makarov. Hammer forging is used to produce the barrels of Makarov pistols (Bonfanti \& De Kinder, 1999).

Munitions International Laboratories Inc (MILI). The Thunder Five model is manufactured using investment casting (Price et al., 2008). This process is also used for firearms of the following calibres: .22 Long Rifle, .32 ACP, .410 Gauge and .45 Colt (Monturo, 2019). The casting process relies on a very expensive specific mould.

Mossberg. The article referring to the Coronet Manufacturing Company (Robinson, 1982) explains that this firm occasionally supplied barrels for Mossberg. Button rifling and broaching processes are used for the machining of these barrels. The manufacturer's website (http://www.mossberg.com/category/series/mossberg-patriot) shows that the Patriot model has a barrel produced with by button rifling.

North American Arms. MILI produced cast barrels for North American Arms, respectively for the Minirevolvers in .22 calibres and the Autauga pistol in (.32 ACP) (Price et al., 2008).

Pietro Beretta. All rifled barrels of the semi-automatic pistol such as APX and Px4 Storm families, or the assault rifles (e.g. ARX160 and CX4 Storm) are produced by cold hammering. The barrels of the 92 series rifled by broaching are an exception due to the barrel locking system (visit the manufacturer, 2020).

Raven Arms. An article not referring to a particular model specifies that Raven's barrels are rifled by hook cutting (Christansen, 1977). They would have six grooves with a left twist. However, an article by Carr (Carr, 1992) mentions that the barrel of the MP- 25 model is rifled by broaching.

Remington. Bonfanti and De Kinder (1999) indicate that Remington relies on button rifling. However, the manufacturer's website (https://www.remington.com) indicates that most rifles have a barrel rifled produced by hammer forging, without giving any information about the handguns. 
Sturm, Ruger \& Co., Inc. In his article on investment casting, Chenow and Lemmer (1994) mention that Ruger is using this manufacturing process. However, according to Bonfanti and De Kinder (1999), the Blackhawk revolvers have barrels manufactured by button rifling, while those of the KP 89 model are rifled by broaching (Bolton-King et al., 2012a). However, according to the manufacturer's website (https://ruger.com), the barrels of current revolvers, among which the New Model Black Hawk and the New Bearcat, are rifled by hammer forging. The same applies to assault rifles, including the AR556, SR-762, SR-22, MINI-14 models and precision rifles. An online video by Ruger confirms that the company mainly uses hammer forging (RugerFirearms, 2014g).

Sabatti S.p.a. All the barrels of the Sabatti company are rifled with the MRR System by cold hammer forging (visit the manufacturer, 2020). This information is also indicated on the manufacturer's website (https://www.sabatti.it/en/mrr-system-rifle-barrels). The visit also reveals that the chamber of the firearm can be manufactured either when hammering the barrel, or after the rifling of the barrel by drilling. During this operation, there may be marks of manufacture in the chamber itself.

Savage Arms. Biasotti (1981) gives the example of Savage rifles in .32-20 Winchester calibre which were rifled with a hook cutting. The Coronet Manufacturing Company seems to have produced barrels for Savage intermittently (Robinson, 1982). The process used would be broaching and button rifling, without specifying any model. The third article describes the results of visits to several firearms manufacturing plants in New England, including Savage Arms (Glass \& Gibson, 1997). Button rifling process is also mentioned for these barrels, without any additional information. Finally, a more recent article shows that the Savage model M-110 has a barrel rifled by button rifling (Hildebrandt, 2005).

Shilen. A study using Shilen rifles states that they are rifled by button rifling (Hall, 1983), which is confirmed by Bonfanti and De Kinder (1999). The official page of the Shilen pistol barrels (http://www.shilen.com/productsPistolBarrels.html) confirms this statement. Although nothing is specified for the barrels of the rifles.

SIG Sauer. During a visit of the factory, Bolton-King et al. found that SIG Sauer relies on two processes to rifle their pistols barrels: cold hammer forging and ECM (Bolton-King, 2017; Bolton-King et al., 2012b). Prior to 2002, all the SIG Sauer barrels were rifled by cold hammer forging method, (e.g. P220 or P225 models). Since 2002, the barrels of duty pistols (e.g. models P226, P250 or SP2022 models) are rifled using ECM, as opposed to rifles and sport pistols barrels which are still produced by hammering. A detailed presentation of the SIG Sauer process is included in (Bolton-King et al., 2012b).

Smith \& Wesson. Biasotti's article informs that the barrels of the Smith \& Wesson .38 Special are rifled by broaching (Biasotti, 1981). Glass and Gibson's article confirm this method is used for many barrels and specified that the barrels of $9 \times 19 \mathrm{~mm}$ Parabellum and .45 ACP calibre had a right twisted groove while the .40 Smith \& Wesson calibre had left twisted grooves (Glass \& Gibson, 1997). According to this reference and the article of DeFrance and Arsdale (2003), most of the Smith \& Wesson revolver barrels are produced by electrochemical methods since 1993. However, broaching is still used for .22 calibre revolver barrels and ported barrels, while the Victory models are rifled by hook cutting (Bonfanti \& De Kinder, 1999; DeFrance \& Arsdale, 2003; Glass \& Gibson, 1997; Heard, 2008). George (1990) includes more details on the Smith \& Wesson model 4006 in .40 Smith \& Wesson calibre. This has a barrel with six grooves twisted left, without any indication of the manufacturing process used. A presentation of the Smith \& Wesson Factory is available online, showing all the manufacturing 
processes of different parts of firearms including the barrel manufacturing (FMGPublications, 2011a, 2011b, 2011c, 2011d, 2011e, 2012).

Sphinx Systems Limited. Their pistols barrels are produced by the German company Lothar Walther, implying button rifling (visit the manufacturer, 2006). Sphinx Systems Limited ceased its activities in 2016.

Springfield Armory. Robinson (1982) mentions that the Coronet Manufacturing Company was producing barrels by button rifling or broaching for the Springfield Armory, particularly for the P9C model which the barrel was produced by broaching (Bolton-King et al., 2012a). A visit of the factory by Glass and Gibson (1997) has highlighted the use of hammer forging, which is confirmed for the .45 ACP calibres and the $9 \times 19 \mathrm{~mm}$ Parabellum calibres of the XD-M ${ }^{\bullet}$ series on the manufacturer's website (https://www.springfield-armory.com).

Star Bonifacio Echeverria, S.A. According to the findings of the research by Bolton-King et al. (2012b), broaching is used to rife the barrels of the Firestar models.

Sterling Arms. According to Berry (1981), all the Sterling barrels for .22 and .25 ACP calibres are produced by button rifling and present ten grooves with a right twist. The barrels for the .380 ACP and $.32 \mathrm{ACP}$ calibres are also produced by button rifling (eight grooves with a right twist instead of six).

Steyr-Mannlicher. The barrels of their sporting rifles are manufactured by hammering (Warlow, 2012).

U.S. Repeating Arms Company. This company uses the hammer forging process (Glass \& Gibson, 1997).

Weatherby. Biasotti's article indicates that the Weatherby .300 Magnum model rifle has a barrel produced by hammer forging (Biasotti, 1981).

Wilson Arms Company. According to the visit by Glass and Gibson to the manufacturer, they rely on different process such as hook cutting, broaching and button rifling, without any indication about the models (Glass \& Gibson, 1997).

Winchester Repeating Arms. The firm Coronet Manufacturing Company produces barrels for the manufacturer Winchester, by button rifling or broaching (Robinson, 1982). The article by Chenow and Lemmer (1994) states that Winchester Repeating Arms also uses investment casting without specifying which models or parts were produced with it.

\subsection{Breeches, firing pins, extractors and other parts}

Carl Walther. Breech faces are produced by milling, the firing pins are manufactured with a lathe by the Swiss manufacture Fredec AG and the magazines by Mecar in Italy (visit the manufacturer, 2007).

Colt's Manufacturing Company. Broaching is used to manufacture the breech face of most models of 1911 Colt Government (Monturo, 2019).

Fratelli Tanfoglio SAS. The steel slide blanks are roughened by a subcontractor and finished by Tanfoglio by milling with a rotating endmill in lateral motion (visit the manufacturer, 2020). The breech face is polished by hand potentially leaving subclass or even individual characteristics (entirely due to the manufacturing process). The firing pins are polished by tumbling in a bath with abrasive stones 
and finished according to the user's requirements (chrome-plated, blued, etc.). The firing pins can be slightly different according to manufacturing tolerances and they are finally retouched by hand with an abrasive paper. Similarly, the extractors are influenced by the manufacturing tolerances and the method of production. The magazines are produced either by Mecar or by Sabatti.

Glock. Breech faces of the Glock pistol calibres are produced by broaching (Monturo, 2019). The plowing marks can be observed on the surface of the parts.

Hi-Point. The extractor of Hi-Point can be produced by blank stamping (Monturo, 2019).

KelTec. Breech faces of the KelTec pistols are produced by broaching (Monturo, 2019).

Lorcin. An article dedicated to the manufacture of Lorcin L380 states that an insert is added to the breech to strengthen it (Collins, 1997). This insert is believed to cause crescent-shaped marks observed on the bases of some cartridges, resulting from the process used to manufacture the inserts (Matty, 1999; Rivera, 2007). The breech face of Lorcin pistols is chrome plated (Monturo, 2019).

Phoenix Arms. The article by Thompson (2015) shows marks left by different Phoenix Arms .25 calibre breech faces on cartridge cases. The author concludes that some concentric circular marks observed on the cases are due to the manufacturing process of the breech face.

Pietro Beretta. Breech faces of the Beretta 92 series are manufactured by milling which have arched marks cause by the movement of the slide into the rotating endmill (Monturo, 2019).

Raven Arms. An article about the firearms of Raven Arms indicates that their breech faces are cut using an automatic lathe and are neither polished nor finished (Christansen, 1977). The impressions that this operation leaves on the produced part induce circular marks on the fired cartridges. No specific model is specified.

Ruger and Company Incorporated. The slides of Ruger are manufactured by investment casting, then milled and finally polished (Gun Talk Media, 2017a). The breech faces of the Ruger model AR-556 and the M77 Mark II semi-automatic rifles are manufactured by milling and show arched marks cause by the movement of the slide into the rotating endmill (Lopez \& Grew, 2000; Monturo, 2019). Ruger has also used the wire EDM process to cut the breech face to the final dimensions. Investment casting is commonly used by Ruger for the manufacture of their revolver frames and barrels (Price et al., 2008). The online content of Ruger Factory includes the complete manufacturing process of the slides and frames (RugerFirearms, 2014a, 2014b, 2014c, 2014d, 2014e, 2014f, 2014g, 2014h, 2014i, 2014j, 2014k, 2014l, 2014m, 2014n, 2015a, 2015b).

Sabatti. The firing pins are made by MIM (visit the manufacturer, 2020). The breech faces are produced by milling and this manufacture process may leave subclass or even individual characteristics (marks of manufacture).

SIG Sauer. The article about the manufacturing of SP2022, P226 and P229 SIG Sauer pistols also explains how the slide is produced (Bolton-King et al., 2012b). After cutting, the raw steel bar is placed through a CNC with several milling machines used to mill the ejection port and cut the breech face. Then the slide is deburred and polished with vibrating stones, these steps also impact the surface of the breech face. Finally, some areas of the slide are hardened by induction. Finally, an optional surface 
treatment (i.e. glass pearl blasting) or a Teflon coating can be applied. More details about the manufacturing process of this part can be found in (Bolton-King et al., 2012b).

Smith \& Wesson. A study on ammunition fired with Smith \& Wesson 40VE Sigma pistols (calibre .40 Smith \& Wesson), relying on information from the company informs that the breech face of this model is produced by broaching (Rivera, 2007). A broached breech face would explain the shear marks left on the head of cartridge cases fired with this model. The online content of the Smith \& Wesson factory shows the processes and machines used for the manufacturing of the slides and frames (FMGPublications, 2011a, 2011b, 2011c, 2011d, 2011e, 2012; Gun Talk Media, 2017c). Specifically, forging is used by Smith \& Wesson for the manufacture of their revolver frames (Gun Talk Media, 2017b).

Sphinx Systems Limited. The firing pins are manufactured by the Swiss manufacture Fredec AG and the magazines by Mecar in Italy. Both use a lathe (visit the manufacturer, 2006). The breech face is manufactured by milling, followed by a polishing step involving a heated wire in an oil bath.

STI Firearms. Breech faces of STI Firearms are described and cut by wire EDM until 2013 (Monturo, 2019).

Taurus. Initially, this company was using the MIM with a final glass beading for the manufacturing of their breech faces which have a granular surface potentially bearing individual characteristics (Thompson, 2015). Nowadays, broaching or milling is likely to be used for models such as the Taurus 92 series, which show arched marks cause by the movement of the slide into the rotating endmill (Monturo, 2019).

\section{DISCUSSION AND CONCLUSION}

Knowledge about firearms manufacturing processes is often described as essential when analysing, comparing and interpreting the marks left on elements of ammunition (Bolton-King, 2017; Bolton-King et al., 2012a; Gallusser, 2014; Lightstone, 2010; Monturo, 2019; Rivera, 2007; Smith, 2011; Tam, 2001). Such information is particularly important when trying to distinguish between individual characteristics occurring accidentally and uniquely, versus subclass characteristics, formed during the manufacturing process and potentially shared by a batch of firearms. The examiner must also be able to predict whether subclass characteristics are likely to be transferred to a cartridge case or projectile, in addition to recognising them (Gallusser, 2014). This understanding is critical because of the legal significance of the scientific conclusion regarding the hypothesis that a bullet, which caused an injury or a death, is linked to a specific firearm (Johnson, 2012).

Only a few articles provide an extensive list of association between processes and manufacturers or models of firearms (Bolton-King, 2017; Smith, 2011). The purpose of this review was to highlight the different sources of information available nowadays regarding the manufacturing of firearms parts. This research shows that conducting a systematic review is challenging. First, this type of information is usually scattered across different type of resources. Besides, the level of detail available is very diverse, depending on the manufacturer. Unlike information such as the materials used, the type of rifling, the number of grooves and lands or otherwise the direction of rifling rotation, the manufacturers rarely disclose information on their manufacturing processes. When they do, it is mainly about the production of the barrel or the breech face, while the firing pin or the ejector are 
rarely described. From a manufacturing point of view, the barrel being an essential part of the firearm, very specific processes have been developed to produce barrels since the beginning of the $20^{\text {th }}$ century. Some of them even became a trademark or were the subject of a patent. From a forensic point of view, the barrel is often the part of a firearm that is most relevant in the investigation of firearm cases. It is due to the fact that the projectile is usually the element of ammunition allowing the strongest link to a questioned firearm from the case. For example, a projectile recovered from a body which has caused a death, is considered as essential to the case and of more value evidentially, as opposed to a cartridge case found on the ground.

Even if a manufacturer mainly uses a specific technique, exceptions are likely to be found, sometimes for a specific model or period of time. Although it is difficult to formalize a systematic approach to obtain this kind of information, the present research suggests that the following steps are essential when studying the manufacturing of a firearm in a forensic context:

1. Consultation of forensic publications related to firearms (articles from peer reviewed journal, books), with a particular focus on specialized literature such as the AFTE journal. The level of detail will depend on the type of research presented (e.g. case report about a specific model or a complete chapter on the history of processes).

2. Consult the official website of the manufacturer, including the technical documentation and the catalogues, which are a rich source of information for specific models. Particular attention should be given to the date of publication of the documentation.

3. Conduct extensive online research, which may lead to complementary content (e.g. videos, discussion forums). Very detailed visual information has been obtained through

4. Contact directly the firearm manufacturers and, if necessary and possible, visit their factories. Although it may be time consuming when working on a case, this would provide the most detailed level of information in each phase of the process (from the raw material to quality control) and can be an excellent opportunity to confirm findings.

Manufacturing techniques are evolving, as well as the design of some firearms parts (e.g. rifling patterns of barrels), showing that a regular update is required when studying this kind of information. Usually, the online content made available by the main manufacturers is the newest and most updated version. Conversely, old documentations may be relevant depending on the firearm used in a case. A good network is essential in those cases, as gunsmiths, collectors, forensic laboratories or anyone with an interest for forensic or firearms matters, are likely to be a valuable source of information.

To conclude, researching the manufacturing process of a firearm in a forensic context can be a challenging step. Nowadays, forensic literature can be complemented with online resources and, depending on the case or the type of firearms, a direct consultation of a manufacturer is always recommended to obtain detailed information.

\section{Acknowledgments}

The authors would like to thank the companies they had the opportunity to visit, and their staff who kindly welcomed them and provided detailed answers about their manufacturing processes. They are also grateful to the reviewers for their insightful comments and proposals to improve this article. 


\section{References}

AFTE Journal. (1973). Polygonal Rifling. AFTE Journal, 5(2), 32-33.

Ashbaugh, D. R. (1999). Quantitative qualitative friction ridge analysis: an introduction to basic and advanced ridgeology. Boca Raton, FL: CRC.

Austin, P. F. (1970). The Identification of Bullets Fired From High-Velocity Rifles with Consecutively Rifled Micro-Groove Barrels. Canadian Society of Forensic Science Journal, 3(1), 1-9.

Berry, L. (1981). Additional Information Concerning Sterling Arms Company. AFTE Journal, 13(2), $16-$ 17.

Biasotti, A. A. (1981). Rifling Methods - A Review and Assessment of the Individual Characteristics Produced. AFTE Journal, 13(3), 34-61.

Bolton-King, R. (2017). Rifling Methods of Factory Fitted 9 mm Luger (9 x 19 mm) Pistol Barrels: A Reference Resource. AFTE Journal, 49(4), 225-238.

Bolton-King, R. S., Bencsik, M., Evans, J. P. O., Smith, C. L., Allsop, D. F., Painter, J. D., \& Cranton, W. M. (2012a). Numerical classification of curvilinear structures for the identification of pistol barrels. Forensic Science International, 220(1), 197-209.

Bolton-King, R. S., Evans, J., Smith, C. L., Painter, J. D., Allsop, D. F., \& Cranton, W. M. (2012b). Manufacturing of SIG Sauer 9 × 19 mm Pistols. AFTE Journal, 44(1), 19-28.

Bonfanti, M. (1997). Revue des procédés de fabrication de certaines parties d'armes à feu. Revue Internationale de Criminologie et de Police Technique (RICPT), 50(4), 460-468.

Bonfanti, M. S., \& De Kinder, J. (1999). The Influence of the Use of Firearms on Their Characteristic Marks. AFTE Journal, 31(3), 318-323.

Carr, J. C. (1992). Lorcin L25 - A Barrel With Class. AFTE Journal, 24(1), 17-21.

Chenow, R. W., \& Lemmer, J. T. (1994). The Use of Investment Castings in the Manufacture of Firearm Components. AFTE Journal, 26(1), 64-76.

Christansen, R. P. (1977). Raven Arms. AFTE Journal, 9(2), 59-63.

Christen, S., \& Jordi, H. R. (2019). Individuality testing of new Glock pistol barrels "Marksman Barrel”. Forensic Science International, 295, 64-71.

Collins, J. M. (1997). Manufacturing the Lorcin L380 and Corresponding Characteristics. AFTE Journal, 29(4), 498-502.

Dallhammer, P. (2018). The Textbook of Pistol Technology and Design: Production - Principles Progress. Germany: Shaker Verlag GmbH.

DeFrance, C. S., \& Arsdale, M. D. V. (2003). Validation Study of Electrochemical Rifling. AFTE Journal, 35(1), 35-37.

Design2PartTradeShow. (2015, Januar 14). Investment Castings for Firearms - Aero Metals [Video file]. Retrieved from https://www.youtube.com/watch?v=cOaNOaq6z6s.

Di Maio, V. (1999). Gunshot wounds: practical aspects of firearms, ballistics, and forensic techniques (2nd ed.). Boca Raton, London, New-York, Washington DC: CRC Press.

Doyle, J. S. (2011). Forensic Links. Retrieved from http://www.firearmsid.com/A forensic.htm

FMGPublications. (2011, February 4). Smith \& Wesson Performance Center Part 1 [Video file]. Retrieved from https://www.youtube.com/watch?v=KSwAP97SrwA.

FMGPublications. (2011, February 4). Smith \& Wesson Performance Center Part 2 [Video file]. Retrieved from https://www.youtube.com/watch?v=13QFwS422HE.

FMGPublications. (2011, February 4). Smith \& Wesson Performance Center Part 3 [Video file]. Retrieved from https://www.youtube.com/watch?v=WRbUn214yUs.

FMGPublications. (2011, February 4). Smith \& Wesson Performance Center Part 4 [Video file]. Retrieved from https://www.youtube.com/watch?v=dpjob0012ql.

FMGPublications. (2011, February 4). Smith \& Wesson Performance Center Part 5 [Video file]. Retrieved from https://www.youtube.com/watch?v=qEIQyaL80Lc.

FMGPublications. (2012, October 23). Smith \& Wesson Performance Center Part6 [Video file]. Retrieved from https://www.youtube.com/watch?v=8iQwrGCT66M. 
Gallusser, A. (Ed.) (2014). Traces d'armes à feu. Expertise des armes à feu et des éléments de munition dans l'investigation criminelle. (2ème édition ed.). Lausanne, Suisse: Presses Polytechniques et Universitaires Romandes.

Garland, P. V. (1987). The Glock 17 Pistol. AFTE Journal, 19(2), 178-178.

George, W. (1990). Smith \& Wesson 10mm and Beretta 9mm. AFTE Journal, 22(3), 288-294.

Glass, S. A., \& Gibson, W. M. (1997). Firearms Factory Tours. AFTE Journal, 29(4), 487-493.

Gun Talk Media. (2017, Januar 21). Casting Ruger Firearms: GunVenture|S1 E5 P4 [Video file]. Retrieved from https://www.youtube.com/watch?v=Mkp5T7sq2tl.

Gun Talk Media. (2017, Januar 21). Forging Guns at Smith \& Wesson: GunVenture|S1 E5 P1 [Video file]. Retrieved from https://www.youtube.com/watch?v=mF4ekcE3k94.

Gun Talk Media. (2017, Januar 21). Touring the Smith \& Wesson Factory: GunVenture|S1 E5 P2 [Video file]. Retrieved from https://www.youtube.com/watch?v=3lw9FTt $7 \mathrm{rl}$.

Haag, L. C. (1977). Heckler \& Koch Polygonal Rifling. AFTE Journal, 9(2), 45-47.

Hall, E. E. (1983). Bullet Markings From Consecutively Rifled Shilen DGA Barrels. AFTE Journal, 15(1), 33-53.

Haviland, J. (2001). The details of accuracy. Varmint Hunter Magazine, 40, 136-143.

Hays, G., Ivan, T., \& Jenzen-Jones, N. R. (2020). Desktop Firearms: Emergent Small Arms Craft production Technologies. Perth: Armament Research Services (ARES).

Heard, B. J. (2008). Handbook of Firearms and Ballistics: Examining and Interpreting Forensic Evidence (2nd Edition ed.). Chichester: John Wiley \& Sons.

Hildebrandt, C. B. (2005). Savage M-110 Series Rifles. AFTE Journal, 37(1), 21-23.

Johnson, T. (2012). Book Review: "Rifling Machines and Methods" By Clifford F. LaBounty. AFTE Journal, 44(4), 291-292.

Kolbe, G. (2010). The making of a rifled barrel. Retrieved from http://www.geoffreykolbe.com/articles/bmart.htm.

Krcma, V. (1996). Fluted and Annular Grooved Barrel Chambers in Firearms. Journal of Forensic Sciences, 41(3), 407-417.

Lansing, J. F. (1988). Electrochemical Machining - A New Barrel Making Process Part 2: Testing the Coonan Arms Model B Pistol and the Reproducibility of Rifling Striae. AFTE Journal, 20(4), 396-403.

Lightstone, L. (2010). The Potential for and Persistence of Subclass Characteristics on the Breech Faces of SW40VE Smith \& Wesson Sigma Pistols. AFTE Journal, 42(4), 308-322.

Lopez, L. L., \& Grew, S. (2000). Consecutively Machined Ruger Bolt Faces. AFTE Journal, 32(1), 19-24.

Mahdavinejad, R. A., \& Hatami, M. R. (2008). ECM rifling tool design and manufacturing. Iranian Journal of Science and Technology, Transaction B: Engineering, 32(4), 341-352.

Matty, B. (1999). Lorcin L9mm and L380 Pistol Breechface Toolmark Patterns. AFTE Journal, 31(2), 134-137.

Matty, W., \& Johnson, T. (1984). A Comparison of Manufacturing Marks on Smith \& Wesson Firing Pins. AFTE Journal, 16(3), 51-56.

Monturo, C. (2019). Forensic Firearm Examination. London, United Kingdom: Academic Press.

Murdock, J. E. (1981). A General Discussion of Gun Barrel Individuality and an Emperical Assessment of The Individuality of Consecutively Button Rifled .22 Caliber Rifle Barrels. AFTE Journal, 13(3), 84-111.

Nichols, R. (2018). Firearm and toolmark identification: The scientific reliability of the forensic science discipline. London, United Kingdom: Academic Press.

Papke, R. E. (1988). Electrochemical Machining: A New Barrel Making Process. AFTE Journal, 20(1), 48-52.

Price, J., Lee, P., \& Rosen, A. (2008). Investment Casting in Barrel Manufacture of the Thunder Five. AFTE Journal, 40(3), 303-308.

Rivera, G. C. (2007). Subclass Characteristics in Smith \& Wesson SW40VE Sigma Pistols. AFTE Journal, 39(3), 253-258. 
Robinson Jr, T. R. (1963). United States Patent No. 3.100.358. Washington, DC: United States Patent Office.

Robinson, M. (1982). Coronet Manufactury Company. AFTE Journal, 14(4), 8.

RugerFirearms. (2014, April 17). Part 1 Ruger How It's Made -- Wax Molding and Gating [Video file]. Retrieved from https://www.youtube.com/watch?v=ZBYw1CT2JiU.

RugerFirearms. (2014, April 30). Part 2 Ruger How It's Made -- Ceramic Shell [Video file]. Retrieved from https://www.youtube.com/watch?v=oriEUaJJEuU.

RugerFirearms. (2014, August 21). Part 3 Ruger How It's Made -- De Wax and Foundry [Video file]. Retrieved from https://www.youtube.com/watch?v=PO4Lpr-mveA.

RugerFirearms. (2014, May 14). Part 4 Ruger How It's Made -- Finishing/Inspection [Video file]. Retrieved from https://www.youtube.com/watch?v=t4Sc7orqyUI.

RugerFirearms. (2014, July 25). Part 5 Ruger How It's Made -- Heat Treat [Video file]. Retrieved from https://www.youtube.com/watch?v=YvoBqkuXDCs.

RugerFirearms. (2014, August 18). Part 6 Ruger How It's Made -- Quality Assurance [Video file]. Retrieved from https://www.youtube.com/watch?v=KmE5feje68s.

RugerFirearms. (2014, August 19). Part 7 Ruger How It's Made -- Barrels [Video file]. Retrieved from https://www.youtube.com/watch?v=8pzL5h2cl80.

RugerFirearms. (2014, September 2). Part 8 Ruger How It's Made -- Stocks [Video file]. Retrieved from https://www.youtube.com/watch?v=h508h9MaB5I\&pbjreload=10.

RugerFirearms. (2014, September 12). Part 9a Ruger How It's Made -- Machining Mini $14{ }^{\circledR}[$ Video file]. Retrieved from https://www.youtube.com/watch?v=-1fJzFyN5jw.

RugerFirearms. (2014, November 4). Part 11. Ruger How It's Made -- Mini-14 ${ }^{\circledR}$ Assembly [Video file]. Retrieved from https://www.youtube.com/watch?v=4Q8PS4xjg I.

RugerFirearms. (2014, November 19). Part 12. Ruger How It's Made -- Range Test \& Packing [Video file]. Retrieved from https://www.youtube.com/watch?v=KD5732hOyhE.

RugerFirearms. (2014, December 4). Part 13. Ruger How It's Made -- Machining the GP100 ${ }^{\circledR}$ [Video file]. Retrieved from https://www.youtube.com/watch?v=2 30kCBWR14.

RugerFirearms. (2014, December 17). Part 14. Ruger How It's Made -- GP100 Assembly [Video file]. Retrieved from https://www.youtube.com/watch?v=ay bCVwFlkQ.

RugerFirearms. (2014, December 30). Part 15. Ruger How It's Made -- Range \& Final Assembly GP100 ${ }^{\circledR}$ [Video file]. Retrieved from https://www.youtube.com/watch?v=J5ylbS K4e4.

RugerFirearms. (2015, May 14). Part 9b Ruger How It's Made -- Machining Mini-14 ${ }^{\circledR}$ [Video file]. Retrieved from https://www.youtube.com/watch?v=srCmeEopB7w.

RugerFirearms. (2015, May 14). Part 10. Ruger How It's Made -- Finishing \& Bluing [Video file]. Retrieved from https://www.youtube.com/watch?v=d82iLeyjLnU.

Smith, J. (2011). Method of Rifling by Manufacturer. AFTE Journal, 43(1), 45-50.

Sugarman, L. (1982). Eddy Manufacturing Co., Caliber 45 Auto Pistol. AFTE Journal, 14(1), 43-43.

Tam, C. K. (2001). Overview of Manufacturing Marks on Center Fire Cartridges. AFTE Journal, 33(2), 112-115.

Thompson, E. (2015). Metal Injection Molded Breech Face of a Taurus Revolver. AFTE Journal, 47(4), 230-231.

Valdez, S. R. (1997). Bullet Identification From H\&K USP Polygonal Barrels. AFTE Journal, 29(3), 307309.

Warlow, T. A. (2012). Firearms, the Law and Forensic Ballistics (3rd Ed ed.). Boca Raton: CRC Press.

Welch, A. K. (2013). History and Manufacturing Process of the Jennings / Bryco / Jimenez Arms Pistols. AFTE Journal, 45(3), 260-266.

Werner, D., Rhumorbarbe, D., Kronseder, P., \& Gallusser, A. (2018). Comparison of three bullet recovery systems. Forensic Science International, 290, 251-257. 
Werner et al. / WIREs Forensic Sci. (2020)

Appendix

\begin{tabular}{|c|c|c|c|c|}
\hline Brand & Model (name or calibre) & Manufacturing process & Subcontractor & References \\
\hline Bauer Firearms Corporation & All & Investment casting & & Chenow \& Lemmer (1994) \\
\hline \multirow[t]{2}{*}{ Bushmaster } & Old models & Broaching ; Button rifling & $\begin{array}{l}\text { Coronet } \\
\text { Manufacturing } \\
\text { Company }\end{array}$ & Robinson (1982) \\
\hline & ACR series & Hammer forging & 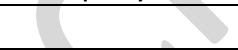 & Manufacturer's website (2020) \\
\hline Carl Walther & All (e.g. PP, P99) & Button rifling & & $\begin{array}{l}\text { Bonfanti \& De Kinder (1999) ; Visit the } \\
\text { manufacturer (2007) ; Bolton-King et } \\
\text { al. (2012a) }\end{array}$ \\
\hline \multirow{4}{*}{ Colt's Manufacturing Company } & $\begin{array}{l}.22 \text { calibres; Other models not } \\
\text { specified }\end{array}$ & Button rifling & & Biasotti (1981) ; Glass \& Gibson (1997) \\
\hline & .45 ACP calibres & Scrape cutting & & Murdock (1981) \\
\hline & Not specified & Investment casting & & Chenow \& Lemmer (1994) \\
\hline & All American 2000 & Broaching & & Bolton-King et al. (2012a) \\
\hline Coonan Arms & Model B in .357 Magnum & ECM & & Lansing (1988) ; Papke (1988) \\
\hline Eddy & Not specified & Button rifling & & Sugarman (1982) \\
\hline Fabrique Nationale (FN) Herstal & Browning Hi-Power MK 1 & Hammer forging & & Bolton-King et al. (2012a) \\
\hline $\begin{array}{l}\text { Fabryka Broni (F. B.) "Łucznik" } \\
\text { Radom }\end{array}$ & Radom Vis Model 35 & Broaching & & Bolton-King et al. (2012a) \\
\hline Fratelli Tanfoglio SAS & All & $\begin{array}{l}\text { Button rifling (rifled conventional and } \\
\text { polygonal barrels); Hammer forging } \\
\text { (rifled conventional and polygonal } \\
\text { barrels) }\end{array}$ & Lothar Walther & Visit the manufacturer (2020) \\
\hline Glock & $17 ; 19$ & Hammer forging & & $\begin{array}{l}\text { Garland (1987) ; Bolton-King et al. } \\
(2012 a)\end{array}$ \\
\hline \multirow{2}{*}{ Heckler \& Koch (H\&K) } & Handguns (e.g. P9S, SP models) & $\begin{array}{l}\text { Hammer forging (rifled polygonal } \\
\text { barrels - hexagonal rifling) }\end{array}$ & & $\begin{array}{l}\text { AFTE Journal (1973) ; Valdez (1997); } \\
\text { Bonfanti \& De Kinder (1999) }\end{array}$ \\
\hline & .40 Smith \& Wesson calibres & $\begin{array}{l}\text { Hammer forging (rifled conventional } \\
\text { barrels) }\end{array}$ & & $\begin{array}{l}\text { AFTE Journal (1973) ; Valdez (1997); } \\
\text { Bonfanti \& De Kinder (1999) }\end{array}$ \\
\hline Iver Johnson \& Painfield carabine & Not specified & Broaching ; Button rifling & $\begin{array}{l}\text { Coronet } \\
\text { Manufacturing } \\
\text { Company }\end{array}$ & Robinson (1982) \\
\hline $\begin{array}{l}\text { Jennings Firearms, Bryco Arms, } \\
\text { Jimenez Arms }\end{array}$ & Not specified & Broaching & & Welch (2013) \\
\hline John Slough of London & Spitfire MK II & Button rifling & & Bolton-King et al. (2012a) \\
\hline Lothar Walther & All & Button rifling & & Manufacturer's website (2020) \\
\hline Lorcin Engineering & L25 pistol ; L380 & Button rifling & & $\begin{array}{l}\text { Carr (1992) ; Collins (1997) ; Bonfanti \& } \\
\text { De Kinder (1999) }\end{array}$ \\
\hline
\end{tabular}


Werner et al. / WIREs Forensic Sci. (2020)

\begin{tabular}{|c|c|c|c|c|}
\hline Brand & Model (name or calibre) & Manufacturing process & Subcontractor & References \\
\hline \multirow{2}{*}{ Marlin Firearms } & .22 calibres & Button rifling & & $\begin{array}{l}\text { Glass \& Gibson (1997) ; Bonfanti \& De } \\
\text { Kinder (1999) }\end{array}$ \\
\hline & 336-R.C. & $\begin{array}{l}\text { Button rifling (rifled micro-groove } \\
\text { barrel) }\end{array}$ & & Bonfanti \& De Kinder (1999) \\
\hline Makarov & All pistols & Hammer forging & s & Bonfanti \& De Kinder (1999) \\
\hline $\begin{array}{l}\text { Munitions International } \\
\text { Laboratories Inc (MILI) }\end{array}$ & $\begin{array}{l}\text { Thunder Five model ; .22 Long Rifle, } \\
.32 \mathrm{ACP}, .410 \text { Gauge and } .45 \text { Colt } \\
\text { calibres }\end{array}$ & Investment casting & & Price et al. (2008) ; Monturo (2019) \\
\hline \multirow[t]{2}{*}{ Mossberg } & Not specified & Broaching ; Button rifling & $\begin{array}{l}\text { Coronet } \\
\text { Manufacturing } \\
\text { Company }\end{array}$ & Robinson (1982) \\
\hline & Patriot & Button rifling & +2 & Manufacturer's website (2020) \\
\hline North American Arms & $\begin{array}{l}\text { Mini-revolver in } .22 \text { calibres; Autauga } \\
\text { (.32 ACP) }\end{array}$ & Investment casting & $\begin{array}{l}\text { Munitions } \\
\text { International } \\
\text { Laboratories Inc } \\
\text { (MILI) }\end{array}$ & Price et al. (2008) \\
\hline \multirow[t]{2}{*}{ Pietro Beretta } & $\begin{array}{l}\text { All (e.g. APX and Px4 Storm families, } \\
\text { ARX160, Cx4 Storm) except } 92 \text { series }\end{array}$ & Hammer forging & & Visit the manufacturer (2020) \\
\hline & 92 series & Broaching & & Visit the manufacturer (2020) \\
\hline \multirow{2}{*}{ Raven Arms } & Not specified & Hook cutting & & Christansen (1977) \\
\hline & MP-25 & Broaching & & Carr (1992) \\
\hline \multirow{2}{*}{ Remington } & Not specified & Button rifling & & Bonfanti \& De Kinder (1999) \\
\hline & Most rifles & Hammer forging & & Manufacturer's website (2020) \\
\hline \multirow{4}{*}{ Sturm, Ruger \& Co., Inc. } & Not specified & Investment casting & & Chenow \& Lemmer (1994) \\
\hline & Blackhawk & Button rifling & & Bonfanti \& De Kinder (1999) \\
\hline & $\begin{array}{l}\text { Current revolvers (e.g. New Model } \\
\text { Black Hawk ; New Bearcat) ; Curent } \\
\text { assault rifles (e.g. AR-556, SR-762, SR- } \\
\text { 22, MINI-14) }\end{array}$ & Hammer forging & & $\begin{array}{l}\text { RugerFirearms (2014g); } \\
\text { Manufacturer's website (2020) }\end{array}$ \\
\hline & KP 89 & Broaching & & Bolton-King et al. (2012a) \\
\hline Sabatti S.p.a. & All & Hammer forging (MRR System) & & $\begin{array}{l}\text { Manufacturer's website (2020); Visit } \\
\text { the manufacturer (2020) }\end{array}$ \\
\hline \multirow{4}{*}{ Savage Arms } & Savage (.32-20 Winchester) & Hook cutting & & Biasotti (1981) \\
\hline & Not specified & Broaching ; button rifling & $\begin{array}{l}\text { Coronet } \\
\text { Manufacturing } \\
\text { Company }\end{array}$ & Robinson (1982) \\
\hline & Not specified & Button rifling & & Glass \& Gibson (1997). \\
\hline & $\mathrm{M}-110$ & Button rifling & & Hildebrandt (2005) \\
\hline
\end{tabular}


Werner et al. / WIREs Forensic Sci. (2020)

\begin{tabular}{|c|c|c|c|c|}
\hline Brand & Model (name or calibre) & Manufacturing process & Subcontractor & References \\
\hline \multirow[t]{2}{*}{ Shilen } & Somes rifles & Button rifling & & $\begin{array}{l}\text { Hall (1983) ; Bonfanti \& De Kinder } \\
\text { (1999) }\end{array}$ \\
\hline & All pistols & Button rifling & & Manufacturer's website (2020) \\
\hline \multirow{2}{*}{ SIG Sauer } & $\begin{array}{l}\text { All firearms before } 2002 \text { (e.g. P220, } \\
\text { P225); Rifles and sport pistols since } \\
2002\end{array}$ & Hammer forging & & $\begin{array}{l}\text { Bolton-King et al. (2012b) ; Bolton-King } \\
\text { (2017) }\end{array}$ \\
\hline & $\begin{array}{l}\text { All duty pistols since } 2002 \text { (e.g. P226, } \\
\text { P250, SP2022 ) }\end{array}$ & $\mathrm{ECM}$ & & $\begin{array}{l}\text { Bolton-King et al. (2012b) ; Bolton-King } \\
(2017)\end{array}$ \\
\hline \multirow{4}{*}{ Smith \& Wesson } & $\begin{array}{l}\text { Many barrels including .38 Special } \\
\text { barrels }\end{array}$ & Broaching & & Biasotti (1981) ; Glass \& Gibson (1997) \\
\hline & Most revolver since 1993 & $\mathrm{ECM}$ & & $\begin{array}{l}\text { Glass \& Gibson (1997) ; DeFrance \& } \\
\text { Arsdale (2003) }\end{array}$ \\
\hline & .22 calibers revolvers; Ported barrels & Broaching & & $\begin{array}{l}\text { Glass \& Gibson (1997) ; Bonfanti \& De } \\
\text { Kinder (1999) ; DeFrance \& Arsdale } \\
\text { (2003) ; Heard (2008) }\end{array}$ \\
\hline & Victory & Hook cutting & & $\begin{array}{l}\text { Glass \& Gibson (1997) ; Bonfanti \& De } \\
\text { Kinder (1999) ; DeFrance \& Arsdale } \\
\text { (2003) ; Heard (2008) }\end{array}$ \\
\hline Sphinx Systems Limited & All & Button rifling & Lothar Walther & Visit the manufacturer (2006) \\
\hline \multirow{3}{*}{ Springfield Armory } & Not specified & Broaching ; button rifling & $\begin{array}{l}\text { Coronet } \\
\text { Manufacturing } \\
\text { Company }\end{array}$ & Robinson (1982) \\
\hline & $\begin{array}{l}\mathrm{XD}-\mathrm{M}^{\circledR} \text { series in } .45 \mathrm{ACP} \text { and } 9 \times 19 \mathrm{~mm} \\
\text { Parabellum calibres }\end{array}$ & Hammer forging & & $\begin{array}{l}\text { Glass \& Gibson (1997) ; Manufacturer's } \\
\text { website (2020) }\end{array}$ \\
\hline & $\mathrm{P9C}$ & Broaching & & Bolton-King et al. (2012a) \\
\hline Star Bonifacio Echeverria, S.A. & Firestar & Broaching & & Bolton-King et al. (2012b) \\
\hline Sterling Arms & $\begin{array}{l}.22, .25 \text { ACP }, .380 \text { Automatic and } .32 \\
\text { ACP calibres }\end{array}$ & Button rifling & & Berry (1981) \\
\hline Steyr-Mannlicher & Sporting rifles & Hammer forging & & Warlow (2012) \\
\hline U.S. Repeating Arms Company & Not specified & Hammer forging & & Glass \& Gibson (1997) \\
\hline Weatherby & .300 Magnum model & Hammer forging & & Biasotti (1981) \\
\hline Wilson Arms Company & Not specified & $\begin{array}{l}\text { Broaching; Button rifling; Hook } \\
\text { cutting }\end{array}$ & & Glass \& Gibson (1997) \\
\hline Winchester Repeating Arms & Not specified & Broaching ; Button rifling & $\begin{array}{l}\text { Coronet } \\
\text { Manufacturing } \\
\text { Company }\end{array}$ & Robinson (1982) \\
\hline
\end{tabular}

Table A1. Manufacturing process for the barrels in alphabetical order of manufacturers. 


\begin{tabular}{|c|c|c|c|c|c|c|}
\hline Brand & Model (name or calibre) & Gun part & Manufacturing process & Subcontractor & Subclass expected & References \\
\hline \multirow{3}{*}{ Carl Walther } & All & Breech face & Milling & & & $\begin{array}{l}\text { Visit the manufacturer } \\
\text { (2007) }\end{array}$ \\
\hline & All & Firing pin & Lathe & Fredec AG & & $\begin{array}{l}\text { Visit the manufacturer } \\
(2007)\end{array}$ \\
\hline & All & Magazine & Lathe & Mecar & ) & $\begin{array}{l}\text { Visit the manufacturer } \\
\text { (2007) }\end{array}$ \\
\hline $\begin{array}{l}\text { Colt's } \\
\text { Manufacturing } \\
\text { Company }\end{array}$ & $\begin{array}{l}\text { Most models of } 1911 \\
\text { Colt Government }\end{array}$ & Breech face & Broaching & & & Monturo (2019) \\
\hline \multirow{5}{*}{$\begin{array}{l}\text { Fratelli Tanfoglio } \\
\text { SAS }\end{array}$} & All & Slide & Milling & & & $\begin{array}{l}\text { Visit the manufacturer } \\
(2020)\end{array}$ \\
\hline & All & Breech face & Polished by hand & 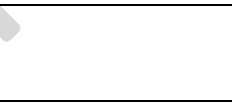 & $\begin{array}{l}\text { Marks of } \\
\text { manufacture }\end{array}$ & $\begin{array}{l}\text { Visit the manufacturer } \\
(2020)\end{array}$ \\
\hline & All & Firing pin & $\begin{array}{l}\text { Polished by tumbling (bath with } \\
\text { abrasive stones), finished according to } \\
\text { the user's requirements (chrome-plated, } \\
\text { blued, etc.) and polished by hand }\end{array}$ & & $\begin{array}{l}\text { Marks of } \\
\text { manufacture }\end{array}$ & $\begin{array}{l}\text { Visit the manufacturer } \\
\text { (2020) }\end{array}$ \\
\hline & All & Extractor & $\begin{array}{l}\text { Polished by tumbling (bath with } \\
\text { abrasive stones), finished according to } \\
\text { the user's requirements (chrome-plated, } \\
\text { blued, etc.) and polished by hand }\end{array}$ & & $\begin{array}{l}\text { Marks of } \\
\text { manufacture }\end{array}$ & $\begin{array}{l}\text { Visit the manufacturer } \\
\text { (2020) }\end{array}$ \\
\hline & All & Magazine & Not specified & $\begin{array}{l}\text { Mecar ; } \\
\text { Sabatti }\end{array}$ & & $\begin{array}{l}\text { Visit the manufacturer } \\
(2020)\end{array}$ \\
\hline Glock & All & Breech face & Broaching & & Plowing marks & Monturo (2019) \\
\hline Hi-Point & All & Extractor & Blank stamping & & & Monturo (2019) \\
\hline KelTec & All & Breech face & Broaching & & & Monturo (2019) \\
\hline \multirow[t]{2}{*}{ Lorcin } & L380 & Breech face & Insert is added & & $\begin{array}{l}\text { Crescent-shaped } \\
\text { marks }\end{array}$ & $\begin{array}{l}\text { Matty (1999) ; Rivera } \\
\text { (2007) }\end{array}$ \\
\hline & Not specified & Breech face & Chrome plated & & & Monturo (2019) \\
\hline Phoenix Arms & .25 calibres & Breech face & Not specified & & $\begin{array}{l}\text { Concentric circular } \\
\text { marks }\end{array}$ & Thompson (2015) \\
\hline Pietro Beretta & 92 series & Breech face & Milling & & Arched marks & Monturo (2019) \\
\hline Raven Arms & Not specified & Breech face & $\begin{array}{l}\text { Cut using an automatic lathe and are neither } \\
\text { polished nor finished }\end{array}$ & & Circular marks & Christansen (1977) \\
\hline
\end{tabular}


Werner et al. / WIREs Forensic Sci. (2020)

\begin{tabular}{|c|c|c|c|c|c|c|}
\hline Brand & Model (name or calibre) & Gun part & Manufacturing process & Subcontractor & Subclass expected & References \\
\hline \multirow{4}{*}{$\begin{array}{l}\text { Ruger and Company } \\
\text { Incorporated }\end{array}$} & All & Slide & $\begin{array}{l}\text { Investment casting, then milled and finally } \\
\text { polished }\end{array}$ & & & Gun Talk Media (2017a) \\
\hline & AR-556 ; M77 Mark II & Breech face & Milling & & Arched marks & $\begin{array}{l}\text { Lopez \& Grew (2000) ; } \\
\text { Monturo (2019) }\end{array}$ \\
\hline & Not specified & Breech face & Wire EDM process & 8 & & Monturo (2019) \\
\hline & Current revolvers & $\begin{array}{l}\text { Frame; } \\
\text { Rifled barrel }\end{array}$ & Investment casting & & & Price et al. (2008) \\
\hline \multirow{3}{*}{ Sabatti } & All & Chamber & Drilling ; Hammer forging & & Marks of manufacture & $\begin{array}{l}\text { Visit the manufacturer } \\
(2020)\end{array}$ \\
\hline & All & Firing pin & MIM & & Marks of manufacture & $\begin{array}{l}\text { Visit the manufacturer } \\
(2020)\end{array}$ \\
\hline & All & Breech face & Milling & & Marks of manufacture & $\begin{array}{l}\text { Visit the manufacturer } \\
(2020)\end{array}$ \\
\hline \multirow{3}{*}{ SIG Sauer } & SP2022 ; P226 ; P229 & Ejection port & Milling & 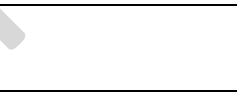 & & $\begin{array}{l}\text { Bolton-King et al. } \\
\text { (2012b) }\end{array}$ \\
\hline & SP2022 ; P226 ; P229 & Breech face & $\begin{array}{l}\text { Milling then eburred and polished with } \\
\text { vibrating stones }\end{array}$ & & & $\begin{array}{l}\text { Bolton-King et al. } \\
(2012 b)\end{array}$ \\
\hline & SP2022 ; P226 ; P229 & Slide & $\begin{array}{l}\text { Eburred and polished with vibrating stones, } \\
\text { hardened by induction and optional surface } \\
\text { treatment (i.e. glass pearl blasting) or a } \\
\text { Teflon coating }\end{array}$ & & & $\begin{array}{l}\text { Bolton-King et al. } \\
(2012 b)\end{array}$ \\
\hline \multirow[t]{2}{*}{ Smith \& Wesson } & $\begin{array}{l}\text { 40VE Sigma (.40 Smith \& } \\
\text { Wesson) }\end{array}$ & Breech face & Broaching & & Shear marks & Rivera (2007) \\
\hline & All revolvers & Frame & Forging & & & Gun Talk Media (2017b) \\
\hline \multirow{3}{*}{$\begin{array}{l}\text { Sphinx Systems } \\
\text { Limited }\end{array}$} & All & Firing pin & Lathe & Fredec AG & & $\begin{array}{l}\text { Visit the manufacturer } \\
(2007)\end{array}$ \\
\hline & All & Magazine & Lathe & Mecar & & $\begin{array}{l}\text { Visit the manufacturer } \\
\text { (2007) }\end{array}$ \\
\hline & All & Breech face & $\begin{array}{l}\text { Milling and polishing (heated wire in an oil } \\
\text { bath) }\end{array}$ & & & $\begin{array}{l}\text { Visit the manufacturer } \\
(2007)\end{array}$ \\
\hline STI Firearms & All & Breech face & Wire EDM process & & & Monturo (2019) \\
\hline \multirow{2}{*}{ Taurus } & Not specified & Breech face & MIM with a final glass beading & & Marks of manufacture & Thompson (2015) \\
\hline & 92 series, among others & Breech face & Broaching ; Milling & & Arched marks & Monturo (2019) \\
\hline $\begin{array}{l}\text { Winchester } \\
\text { Repeating Arms }\end{array}$ & Not specified & Not specified & Investment casting & & & $\begin{array}{l}\text { Chenow \& Lemmer } \\
\text { (1994) }\end{array}$ \\
\hline
\end{tabular}

Table A2. Manufacturing process for the other parts of firearms (breech face, the firing pin, etc.) in alphabetical order of manufacturers. 